\title{
Evaluating the uses and environmental characteristics of 40 public parks and squares in Barcelona by means of systematic observation / Evaluación de los usos y características ambientales de 40 parques y plazas en Barcelona mediante observación sistemática
}

\author{
Sergi Valera, Félix Pérez-Tejera, M. Teresa Anguera \& Laura Sicilia
}

To cite this article: Sergi Valera, Félix Pérez-Tejera, M. Teresa Anguera \& Laura Sicilia (2018): Evaluating the uses and environmental characteristics of 40 public parks and squares in Barcelona by means of systematic observation / Evaluación de los usos y características ambientales de 40 parques y plazas en Barcelona mediante observación sistemática, Psyecology, DOI: 10.1080/21711976.2018.1432525

To link to this article: https://doi.org/10.1080/21711976.2018.1432525

Published online: 28 Feb 2018.

Submit your article to this journal 주

Q View related articles ¿

View Crossmark data $[\pi$ 


\title{
Evaluating the uses and environmental characteristics of 40 public parks and squares in Barcelona by means of systematic observation / Evaluación de los usos y características ambientales de 40 parques y plazas en Barcelona mediante observación sistemática
}

\author{
Sergi Valera (1), Félix Pérez-Tejera, M. Teresa Anguera (D, and Laura Sicilia
}

\section{Universitat de Barcelona}

(Received 8 May 2016; accepted 11 September 2017)

\begin{abstract}
This paper presents an ad hoc instrument for the observation and recording of public space usage based on the combination of field formats and category systems. The EXOdES (Observational Examination of Space) instrument was applied to the analysis of 40 public spaces in the city of Barcelona as part of the collaboration agreement established with the Barcelona City Department of Prevention Services.

It describes the theoretical foundations on which the research conducted is based, especially those pertaining to the social quality of public spaces, as well as the theories generated around the concept of public insecurity. In turn, it advocates the role of observational methodology as a valid instrument in psychosocial research, especially when analysing the dynamics of public urban spaces.

The results show certain characteristics of the patterns of usage of the public spaces studied based on the analysis of differences in terms of the gender, age and seemingly immigrant/native origin of users, as well as the diversity of uses found and the influence of environmental variables.
\end{abstract}

Keywords: public space; observational instrument; field format; category system; uses of space

Resumen: Se presenta un instrumento ad hoc de observación y registro ad hoc de espacios públicos basado en la combinación de formato de campo y sistemas de categorías. El EXOdES (Examen Observacional de Espacios) se ha aplicado para analizar 40 espacios públicos de la ciudad de Barcelona en el

\footnotetext{
*Sergi Valera is a member of the PsicoSAO Research Group on Social, Environmental and Organizational Psychology (2017 SGR 564) / Sergi Valera es miembro del Grupo de Investigación en Psicología Social, Ambiental y Organizacional-PsicoSAO (2014 SRG 992)

English version: pp. 1-16 / Versión en español: pp. 17-32

References / Referencias: pp. 32-34

Translated from Spanish / Traducción del español: Anna Moorby

Authors' Address / Correspondencia con los autores: Sergi Valera, Departamento de Psicología Social y de Psicología Cuantitativa, Universitat de Barcelona, Passeig de la Vall d'Hebrón, 171, 08035 Barcelona, España. E-mail: svalera@ub.edu
} 
marco de un convenio de colaboración con la Dirección de Servicios de Prevención del Ayuntamiento.

Se describen las bases teóricas sobre las que se fundamenta la investigación, especialmente las que hacen referencia a la calidad social de los espacios públicos, así como a las teorías generadas en torno al concepto de inseguridad ciudadana. A su vez se reivindica el papel de la metodología observacional como instrumento válido para la investigación psicosocial, especialmente en el análisis de las dinámicas de los espacios públicos urbanos.

Los resultados muestran ciertas características de los patrones de utilización de los espacios públicos estudiados a partir del análisis de las diferencias por género, edad y origen aparentemente inmigrante/autóctono, así como el grado de diversidad de usos encontrados y la influencia de las variables de carácter ambiental.

Palabras clave: espacio público; instrumento de observación; formato de campo; sistema de categorías; usos del espacio

Public spaces, such as urban squares, parks and gardens, have multiple benefits for the physical, psychological and community health of people. These types of spaces favour physical activity (Godbey, 2009), they have restorative effects when they include natural elements (Ulrich et al., 1991), and they provide the ideal context for the development of place identity, social cohesion and a sense of community (Catell, Dines, Gesler \& Curtis, 2008). In a qualitative review of the use of urban parks, concern with safety is highlighted as the main reason that would lead some citizens to avoid such spaces, especially due to the presence of 'undesirable users' such as drug dealers, tramps or homeless people, and other aspects related to personal safety such as the possibility of becoming a victim of crime or the presence of broken glass or syringes (McCormack, Rock, Toohey, \& Hignell, 2010).

A perceived lack of public safety has been defined as 'the problem of our time' (Amerio \& Roccato, 2005). Unlike the experience of being a victim of crime itself, fear of crime is something that everyone experiences to a greater or lesser extent at some time in their lives. The negative effects at an individual level include anxiety, feelings of rage, frustration, desperation, lack of confidence and dissatisfaction with life (Miceli, Roccato, \& Rosato, 2004; Warr, 2000). The avoidance measures activated by people to reduce the likelihood of being a victim of crime include restriction of routines, spending more time at home, limiting external activities to certain spaces and times of day perceived to be safer and avoiding certain areas in the city, using public transport or going out at night. The literature usually agrees that these social and spatial restrictions designed to avoid risk situations particularly affect women (Gardner, 1990; Pain, 2000, the elderly (Lindesay, 1996), and children (Valentine \& McKendrick, 1997).

At a community level, a perceived lack of safety has important consequences. Some people might limit contact with certain types of people, avoiding strangers, groups of youths, people of different races or ethnic groups or those wearing dirty clothes or with poor personal hygiene (Miethe, 1995). All of this facilitates a decline in social cohesion and solidarity, a breakdown in the sense of community and lower informal control over the conditions of one's own neighbourhood, 
which contributes to the greater degradation of certain enclaves and generates ideal conditions to attract crime (Skogan, 1986).

As for environmental factors, certain aspects of space have a more or less direct relationship with this lack of perceived safety. Inadequate lighting, the existence of concealed areas or places with low visual control, the presence of graffiti or signs of vandalism and the presence of dirt, grime and other symptoms of neglect are some of the most important ones (Hunter, 1978; Lagrange, Ferraro, \& Supancic, 1992; Wilson \& Kelling, 1982).

Although different theories and models have emerged in an attempt to explain the determining factors of a perceived lack of safety (Carro, Valera, \& Vidal, 2010; Taylor \& Hale, 1986; Valera \& Guardia, 2014), much less attention has been paid to studying the consequences of fear of crime in patterns of usage in public urban spaces. It is a logical and unavoidable consequence that environmental psychology should try to articulate methods capable of analysing the main aspects that are sensitive to the definition of public space and its transformations. Knowing the uses, actors and interaction dynamics that characterize certain urban spaces would be the first step in detecting inequalities in access among certain groups and potential conflicts of coexistence. This is particularly important at a time when uses of public urban spaces in cities are becoming increasingly complex as a consequence of greater diversity, the existence of new social actors and the widening of the socio-economic gap (Subirats, 2006). A great many authors are beginning to detect the loss of the urban public space (Innerarity, 2006; Low, 2005; Low, Taplin, \& Scheld, 2005) in favour of a 'mass private space' that is much more controlled and panopticized - in other words, safer (Low, 2003).

\begin{abstract}
Aims
The main aim of this article is to present an ad hoc instrument to observe and record the uses of public space and environmental characteristics: EXOdES (Observational Examination of Spaces). The instrument has been used to analyse a sample of 40 public parks and squares in Barcelona. This paper will set out the procedure used for recording synchronic observational data and will present relational results between criteria corresponding to key aspects in the analysis of public spaces: type of users, diversity of uses and environmental characteristics. This article also aims to carry out an exploratory study through the application of observational methodology capable of detecting any occupancy patterns that exist in the public space.
\end{abstract}

\title{
Method
}

\section{Research context}

The fieldwork was conducted as part of a collaboration agreement between the University of Barcelona's Department of Social Psychology and the City Department of Prevention Services. The final sample of public spaces encompassed 40 public parks and squares. The selection criteria included geographical 
representativeness and a proportionally adequate distribution of spaces regarding the level of perceived safety, according to data from local agents, police and the Victimization Survey of Catalonia. Other factors were also considered, such as proximity (10 observation routes were set up with four spaces each, and a maximum commute time of 15 minutes between spaces), communicability, possibility of observer discretion, etc. Figure 1 shows all the parks and squares included in the final sample.

\section{Participants}

A team of 10 people - non-experts in observational methodology or psychology - were responsible for conducting the observational sessions, coordinated jointly between the Barcelona City Department of Prevention Services and researchers from the University of Barcelona. Over the course of five weeks, the team was given training in observational methodology, in using the observation and recording instrument and in the process of standardizing criteria when evaluating each of the dimensions.

\section{Observation instrument}

The observational instrument proposed (EXOdES) includes the following six dimensions or macrocriteria, each one of which is broken down into the relevant subcriteria:

(1) Temporal location: date of the observational session and exact time of each record entry.

(2) Spatial location: position of each user in the public space and specific location with regard to installations or public furniture.

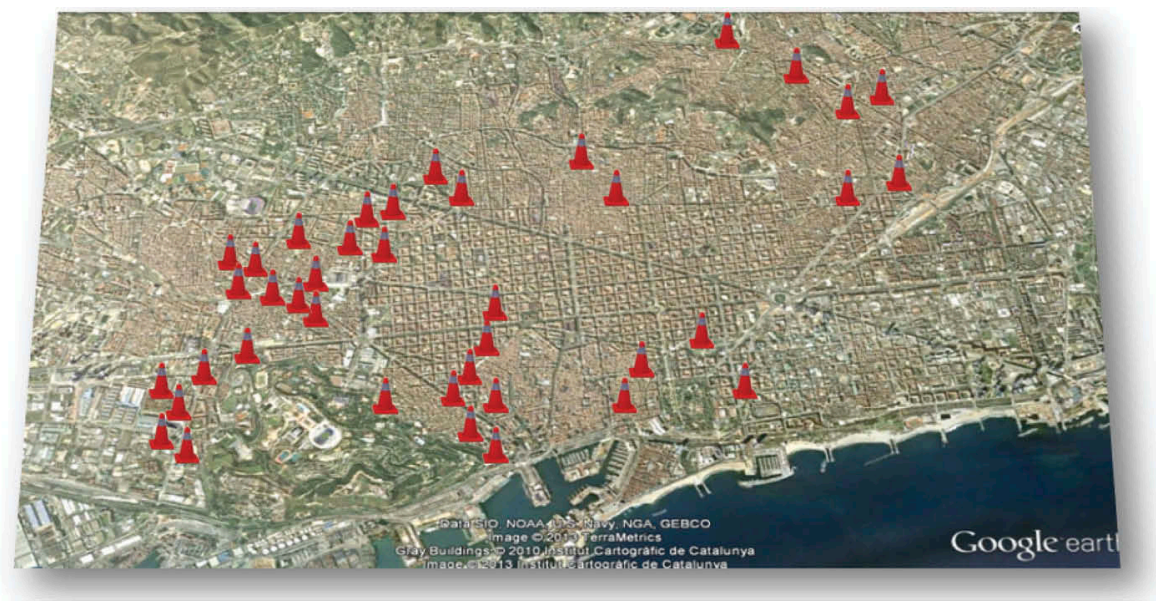

Figure 1. The 40 public spaces analysed. 
(3) Description of users: taking into account gender, age bracket, whether the people were on their own or in a group,

(4) Uses of the space: main activities of the actors in the public space, presence of vehicles, dogs, evident signs of alcohol and/or substance consumption, and verbal and/or physical violence.

(5) Psychosocial factors: seemingly native or immigrant origin, and potential signs of belonging to a certain social group (for example, Latino gangs, tourists) or signs of poverty (homelessness).

(6) Environmental factors: characterization of the immediate surroundings in terms of lighting, dirt and grime, graffiti and visual control, as well as upkeep of rubbish bins and containers and garden areas.

The observational instrument encompasses 24 subcriteria, corresponding to the six criteria indicated previously, organized into columns (Figure 2). Each row corresponds to the recording of each of the observational units, where the codes corresponding to the different subcriteria are shown.

\section{Procedure}

We employed an observational design, which, according to the designs described by Anguera, Blanco-Villaseñor, and Losada (2001), can be classified as nomothetic, follow-up and multidimensional. There is a non-participant single observer in each situation. The observers had been trained to be as inconspicuous as possible to the other users of the public space. In each case, the observer had to choose a place that provided good visibility of the space, where they could comfortably observe and

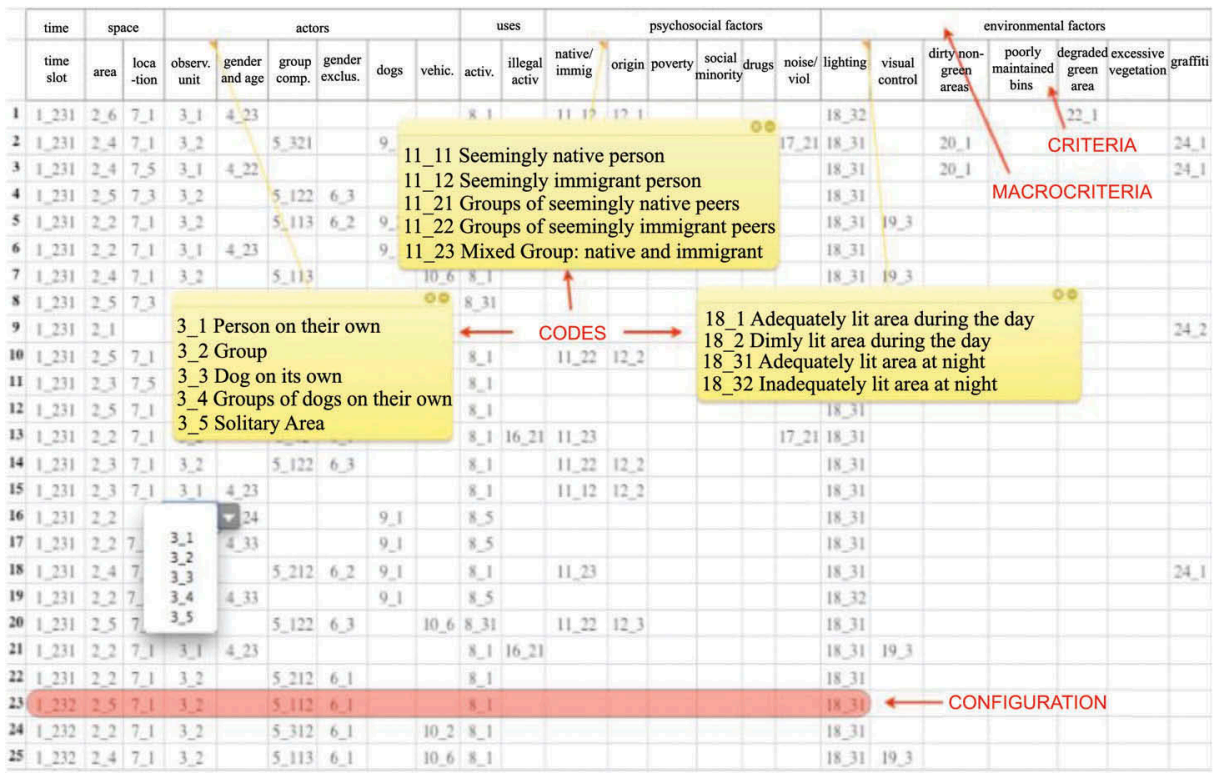

Figure 2. The EXOdES instrument. 
record everything happening in the area. The observer always followed a screening process for intrasessional observational sampling, which entailed observing and recording a specific event that fit the selection criteria established (use of the space) without taking into account events that happened simultaneously. When the observer had finished making an entry, they would then turn their attention to another event (another row in the record code matrix), and so on and so forth until the session was complete. To ensure that all observers were able to situate users of spaces following the same criterion, all the spaces were visited several times and maps were created showing their boundaries. In some cases, the space had to be divided into different areas, following the logic of the spatial configuration itself and the uses detected.

Successive observational sessions in a single space and at the same time slot were carried out by various observers (minimum three different observers) in order to reduce individual bias. These sessions would, in turn, take place on different days of the week (minimum three different days) to favour heterogeneity of uses encountered. Between four and six observational sessions were carried out for each of the 40 spaces and in each of the eight time slots (four in the morning/early afternoon and four in the late afternoon/evening) (Table 1). If weather conditions were unfavourable, the session would be cancelled.

The final results yielded a total of 1,510 observation sessions, each lasting 45 minutes, giving a total of 35,946 records of activities and users of the public spaces analysed (Table 1).

Regarding data quality control, concordance analyses showed acceptable levels of inter-observer reliability and criterion validity (Table 2).

\section{Results}

\section{Type of users}

The results obtained show, in general terms, a clear predominance of male over female presence, especially when the observation unit was a person on their own. The proportion between men and women was three to one; in other words, for

Table 1. Number of public spaces visited between one and six different times in each of the timeslots established.

\begin{tabular}{lrlllllll}
\hline & & 1 & 2 & 3 & 4 & 5 & 6 & \\
\hline Morning/early afternoon & $10: 00-11: 00$ & 40 & 40 & 40 & 40 & 30 & 2 & 192 \\
& $11: 00-12: 00$ & 40 & 40 & 40 & 40 & 29 & 2 & 191 \\
& $12: 00-13: 00$ & 40 & 40 & 40 & 40 & 29 & 2 & 191 \\
& $13: 00-14: 00$ & 40 & 40 & 40 & 40 & 27 & 1 & 188 \\
Late afternoon/evening & $16: 00-17: 00$ & 40 & 40 & 40 & 39 & 31 & 0 & 190 \\
& $17: 00-18: 00$ & 40 & 40 & 40 & 39 & 30 & 0 & 189 \\
& $18: 00-19: 00$ & 40 & 40 & 40 & 38 & 29 & 0 & 187 \\
& $19: 00-20: 00$ & 40 & 40 & 40 & 38 & 24 & 0 & 182 \\
& & 320 & 320 & 320 & 314 & 229 & 7 & 1,510 \\
\hline
\end{tabular}




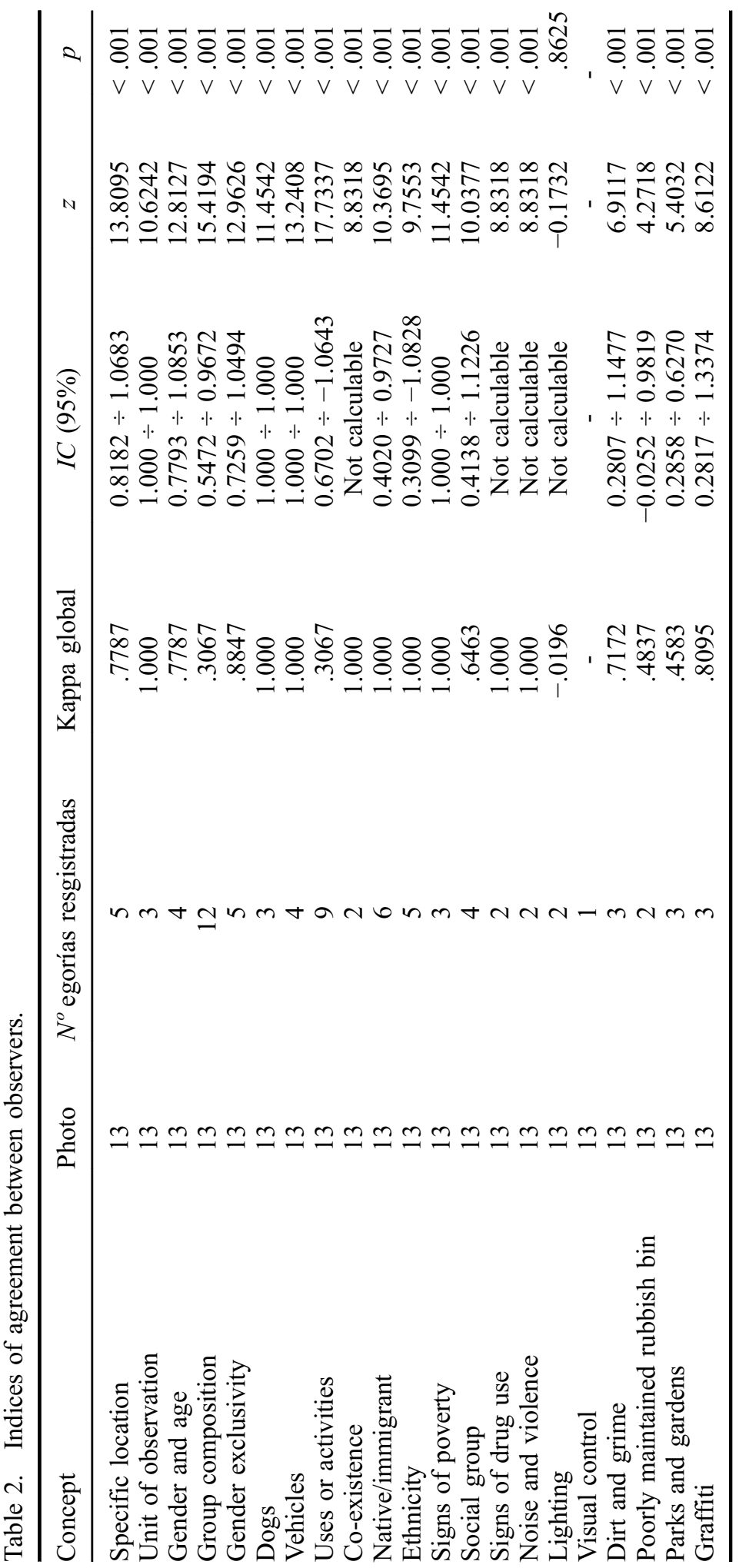


every woman who uses the public space, a total of three men also use that space, a difference that remains stable throughout the different time slots (Figure 3).

The lower presence of women on their own in the public space is observed more among the immigrant population $\left(\chi^{2}=97.69, d f=1, p=<.001\right)$ (Figure 4) and decreases significantly as age increases $\left(\chi^{2}=192.978, d f=3, p=<.001\right)$ (Figure 5).

As for groups of people, the proportion of groups made up exclusively of people in the same age bracket differs according to the different spaces studied (Figure 6). Hence, groups made up just of children represent 6.54\% (IC 95\%: 2.99\%-10.08\%), those made up of teenagers and youths represent $18.62 \%$ (IC 95\%: $15.08 \%-22.16 \%$ ), adults represent $24.27 \%$ (IC 95\%: $20.72 \%-27.81 \%$ ), and elderly people represent $9.48 \%$ (IC 95\%: $5.94 \%-13.02 \%$ ). The same is observed when comparing the proportion of groups of people according to apparent origin (Figure 7). Groups made up exclusively of seemingly native people represent 75.00\% (IC 95\%: 73.12\%-76.88\%), whereas those made up of seemingly immigrant people represent $17.54 \%$ (IC 95\%: 15.66\%-19.42\%),

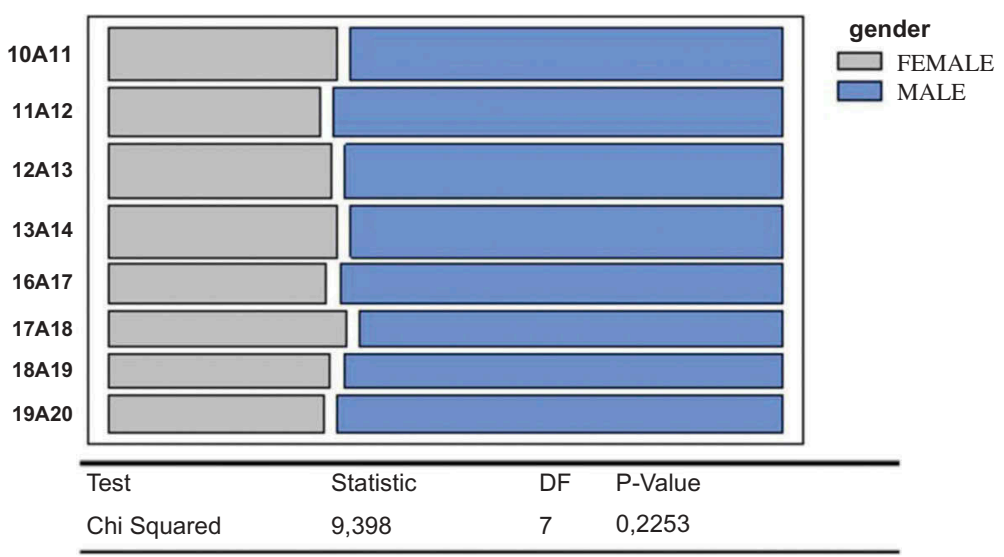

Figure 3. Mosaic graph for timeslots according to gender and comparison test.

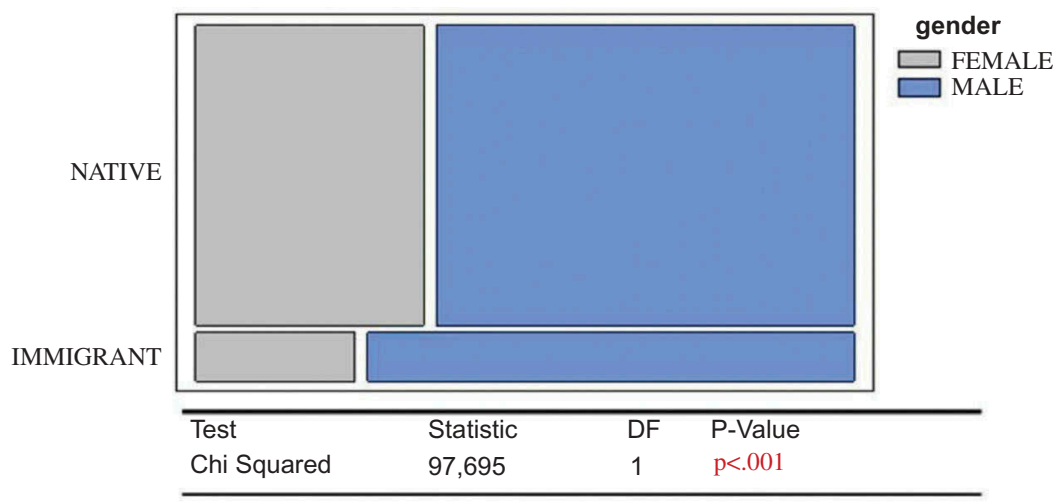

Figure 4. Mosaic graph for origin according to gender and comparison test. 


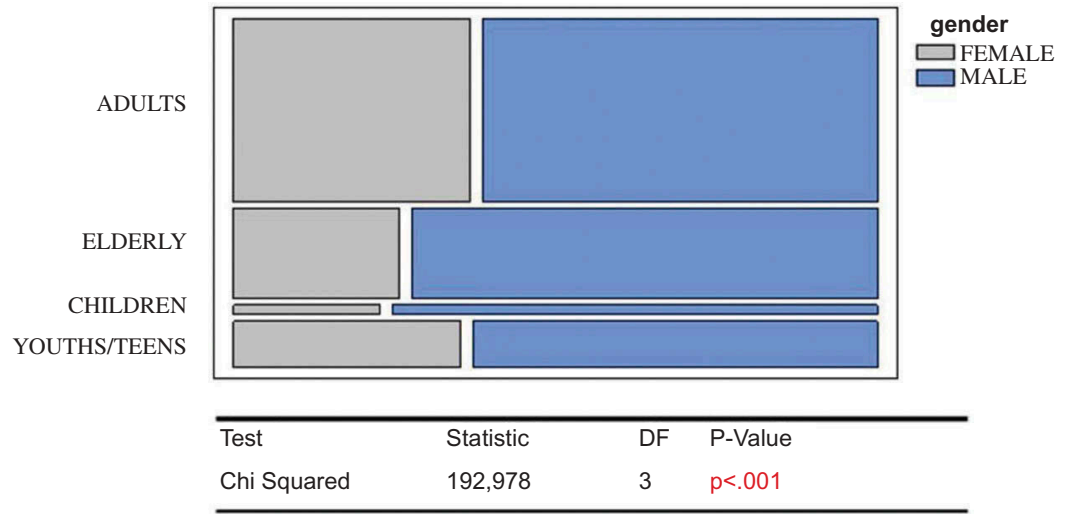

Figure 5. Mosaic graph for age according to gender and comparison test.

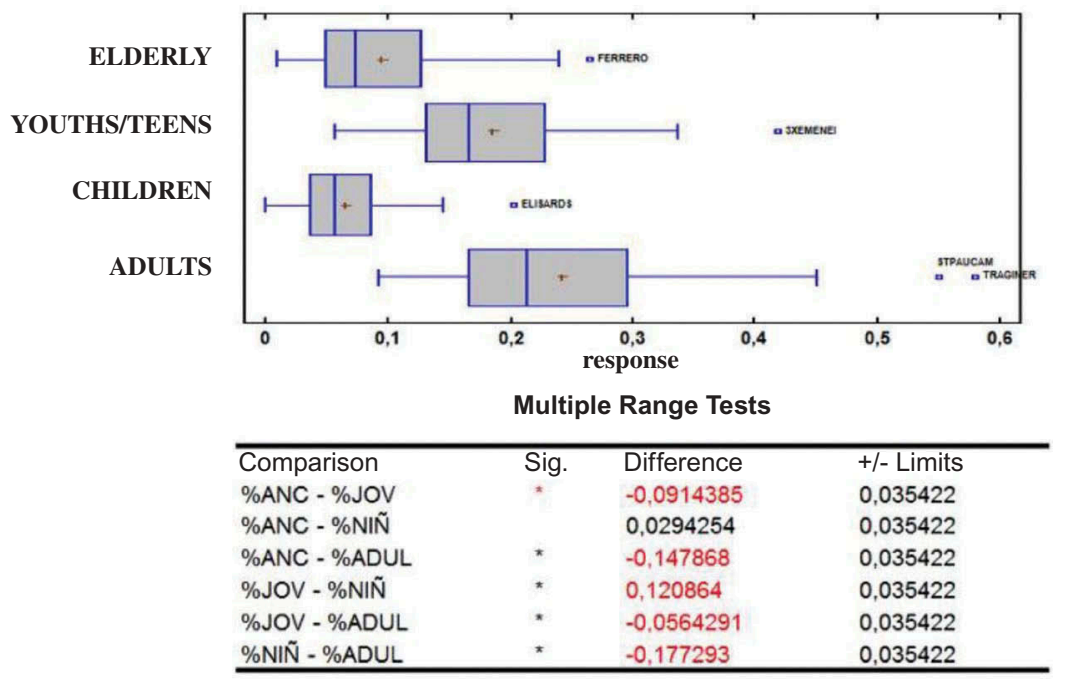

Figure 6. Box graphs for spaces according to age and comparison test.

and mixed groups with regard to origin only account for $7.43 \%$ (IC 95\%: $5.54 \%$ $9.31 \%$ ). All of this indicates processes of spatial segregation according to age and origin in the public spaces studied.

Examination of these data by means of correspondence analysis offers an even greater explanation of these effects. Figure 8 clearly shows how the different public spaces analysed are distributed according to the observational values of the subcriterion person on their own according to a vertical axis 'male presence/female presence', and in turn form three constellations around the values young and adult males, girls, young and adult females and elderly people, both male and female. In other words, elderly people, young and adult women, and young and adult men are not distributed homogeneously in the spaces studied; rather, environmental preferences are observed along 


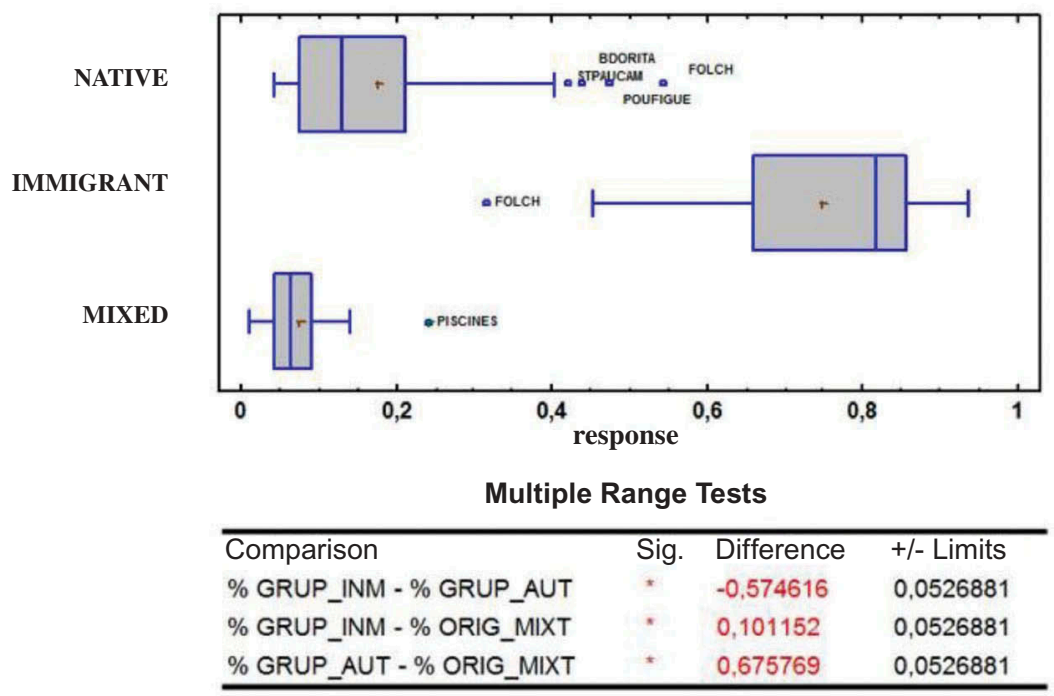

Figure 7. Box graphs for spaces according to origin and comparison test.

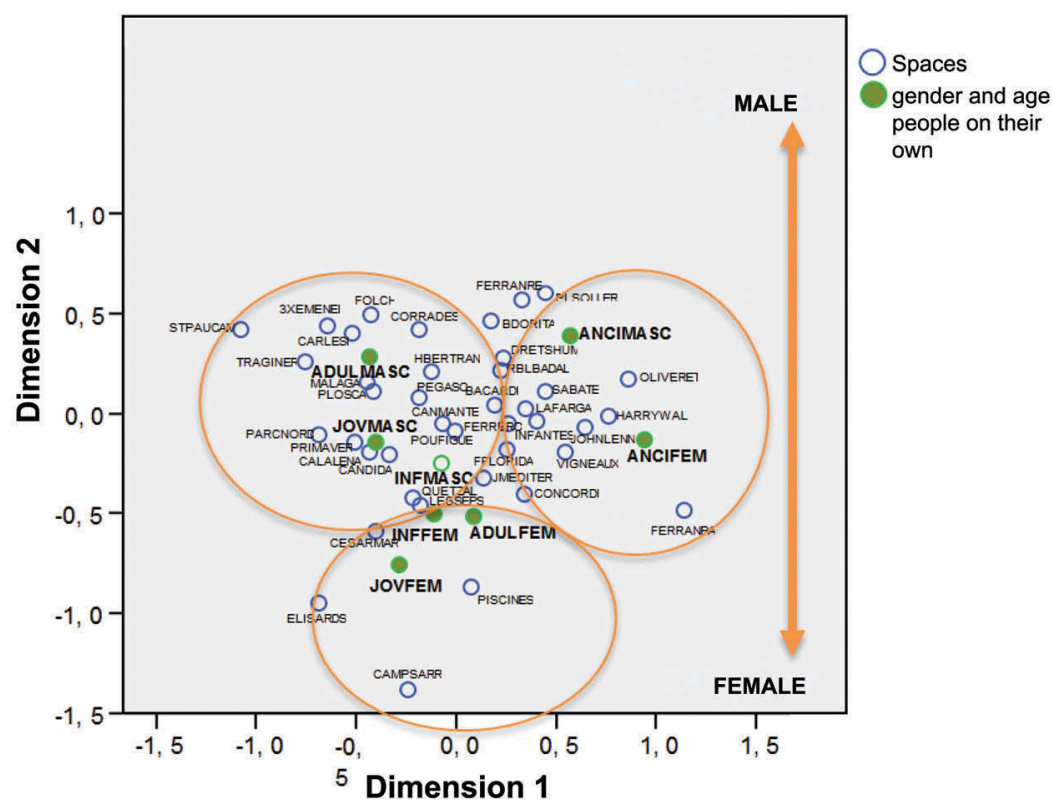

Figure 8. Results of the correspondence analysis for the criterion gender and age of people on their own.

with processes of spatial segregation according to the age and gender of the people who are alone in the public space.

The characterization of spaces according to gender also appears abundantly clear when the unit of observation is groups of people. Figure 9 shows how the parks and squares analysed are distributed in the Euclidean space according to a horizontal axis 


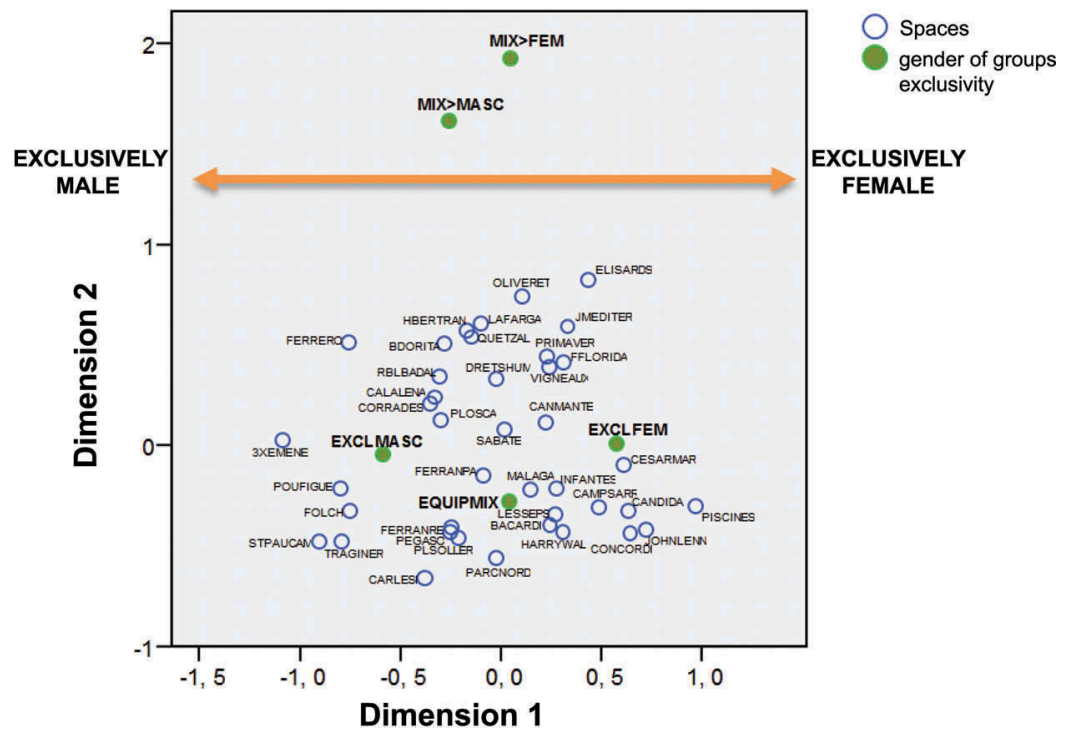

Figure 9. Results of the correspondence analysis for the criterion gender of groups.

'exclusively male groups/exclusively female groups'. Consequently, there are spaces in which the presence of groups made up exclusively of men or women is much more habitual.

The spaces analysed also differ with regard to the presence of seemingly native or immigrant people. Figure 10 shows the distribution of spaces and values of this subcriterion following a vertical 'person/group' pattern and a horizontal 'native/ immigrant' pattern, indicating processes of spatial segregation with regard to the ostensibly native or immigrant origin of the people who utilize the spaces studied.

\section{Uses of the space}

Correspondence analysis shows a clustering of uses, with the category being or talking in the space as the central element. Around this core, a peripheral belt is configured that encompasses the activities of walking, playing and sport (Figure 11).

The most interesting effect appears when observing the frequency of activities and uses according to the space and time slot. Hence, two profiles of public spaces are defined: firstly, there are spaces in which, where the main activity is being or talking, this activity differs extraordinarily from the other activities in terms of frequency. In other words, there is a significant leap between this and the other uses, with very low levels of observed frequency. Figure 12(a) shows three representative spaces of this profile in which the limit of 20 observations per timeslot marks the difference between the main activity and the other residual activities.

The other group of spaces is characterized by a greater frequency of other activities as well as the main activity, in the majority of timeslots. The diversity of uses is, as shown in Figure 12(b), the main characteristic of these spaces where, as well as being and talking, uses such as walking or playing also appear. 


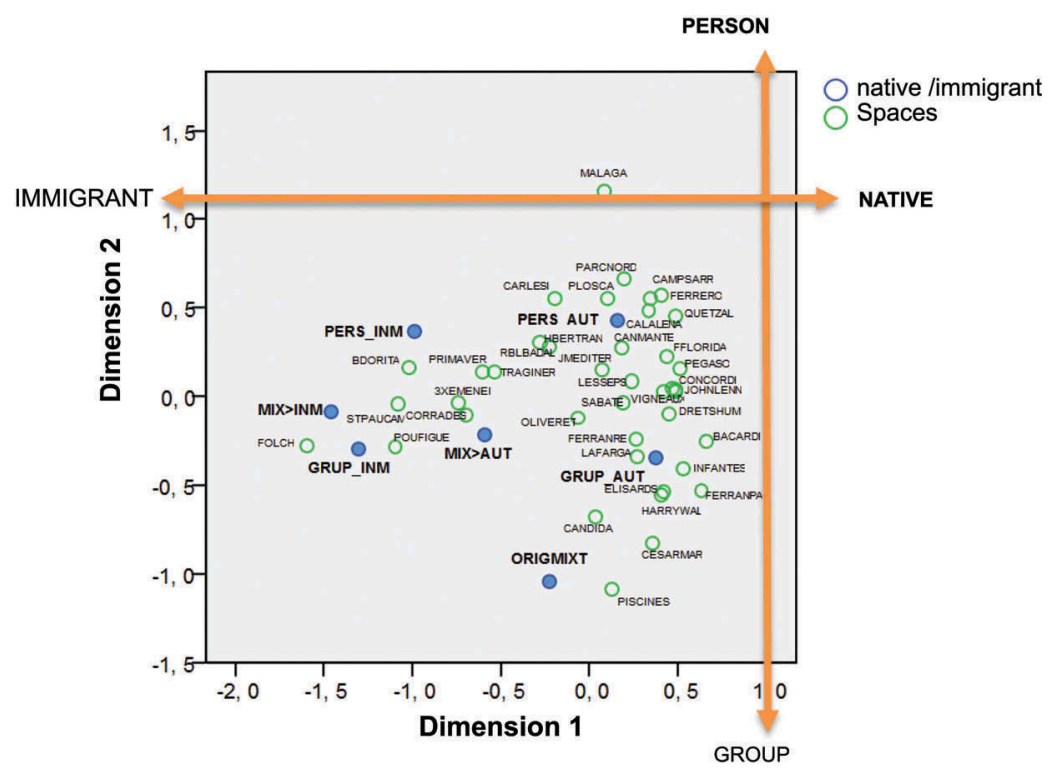

Figure 10. Results of the correspondence analysis for the criterion apparent origin.

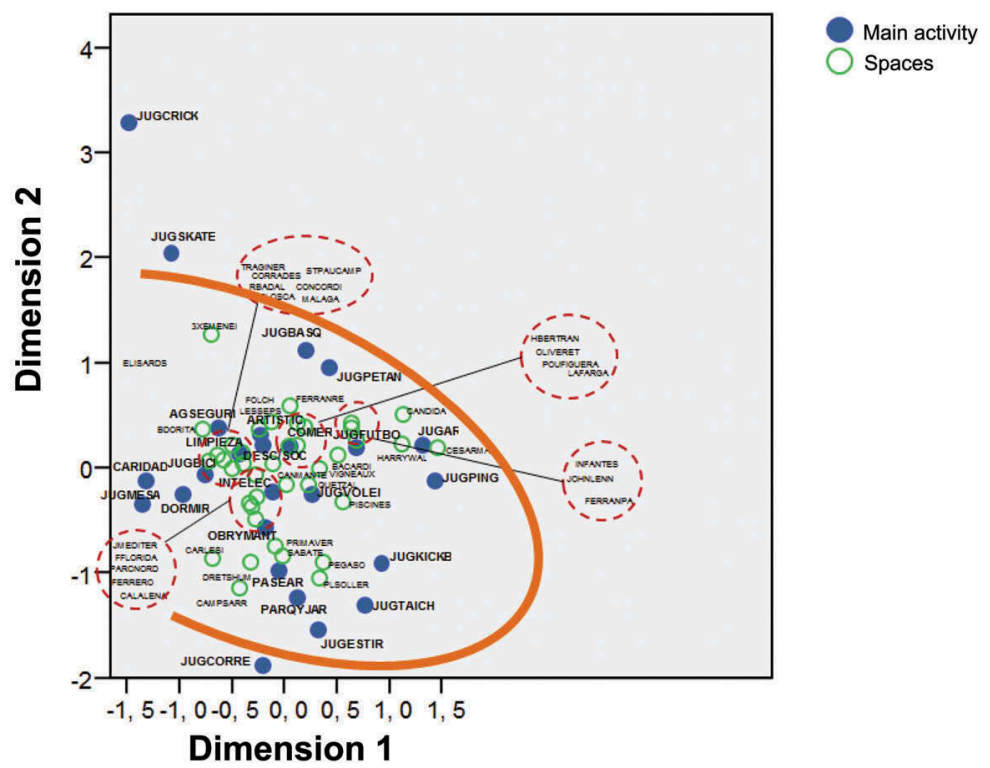

Figure 11. Results of the correspondence analysis for the criterion activities in the space.

\section{Environmental factors}

The presence of dirt and grime, vandalism, problems with lighting or visual control, and signs of environmental degradation appear with very low frequency percentages. In spite of this, statistically significant relations were found in line with our expectations based on the theory: a greater presence of youths was 
(a)

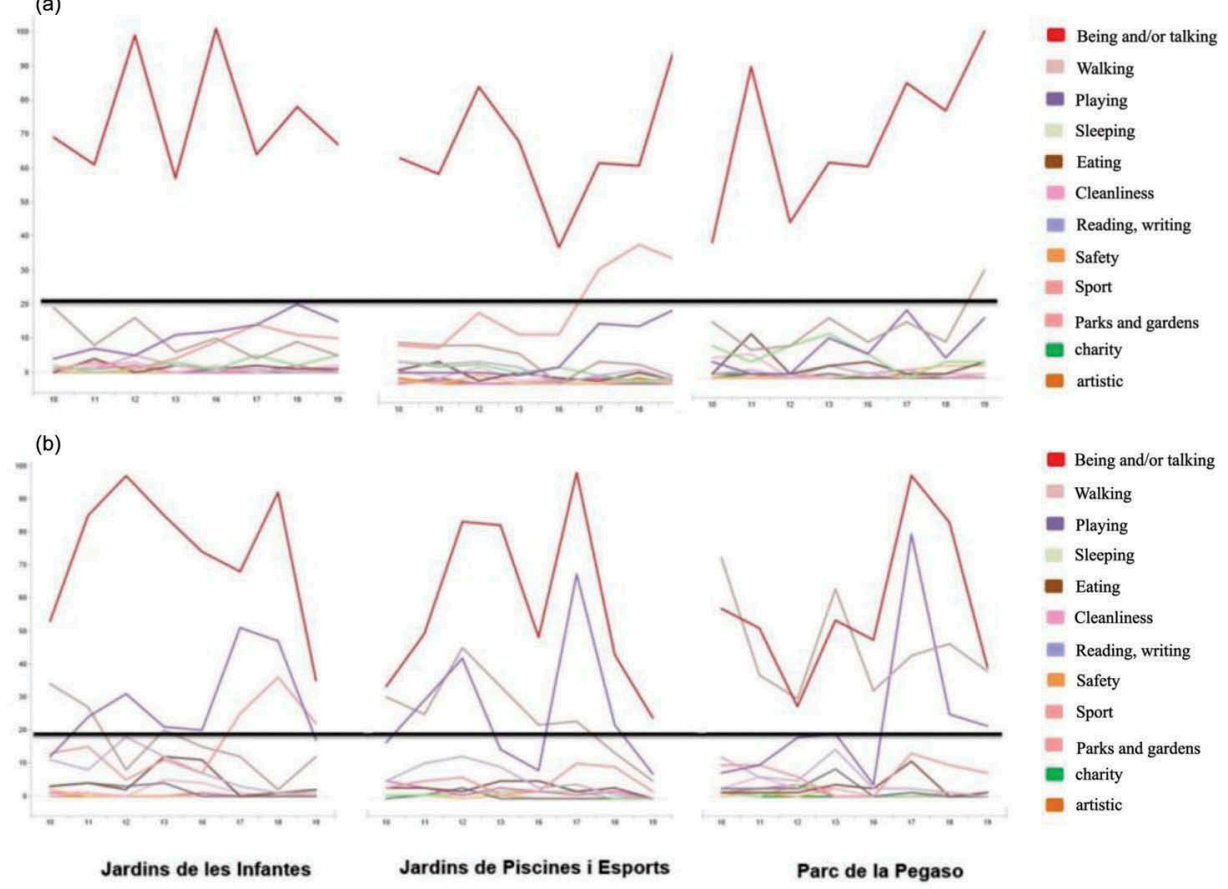

Figure 12. (a) Results of three representative spaces of the profile encompassing low diversity of activities in relation to the timeslots. (b) Results of the three representative spaces of the profile encompassing high diversity of activities in relation to the timeslots.

observed in areas with graffiti $\left(\chi^{2}=12.428, d f=3, p=.0061\right)$ (Figure 13), more problematic uses in areas with insufficient lighting $\left(\chi^{2}=99.724, d f=1, p<.001\right)$ (Figure 14), greater presence of young and adult males in hidden/concealed areas $\left(\chi^{2}=125.955, d f=6, p<.001\right)$ (Figure 15$)$ and a decreased use of the space by women in less clean areas $\left(\chi^{2}=54.377, d f=2, p<.001\right)$ (Figure 16).

\section{Discussion and conclusions}

The public space must guarantee in terms of equality the appropriation by different social, cultural, gender and age collectives (Borja \& Muxí, 2000). Knowing which types of users and activities can be found in a certain public space provides objective information about the patterns of usage found in public spaces. Analysis of the users of public parks and squares studied here offers some interesting data in terms of the clearly differentiated profiles of spaces. Firstly, although a large number of spaces are situated in mixed or intermediate positions with regard to the types of users that frequent them, a good number are clearly polarized with regard to the gender, age or origin of users, both in terms of people using these spaces alone or in groups, which reflects environmental preferences, avoidance behaviours and processes of spatial segregation. There are certain parks and squares that are clearly masculinized, whereas others are more feminized or mixed with regard to gender, both when the 


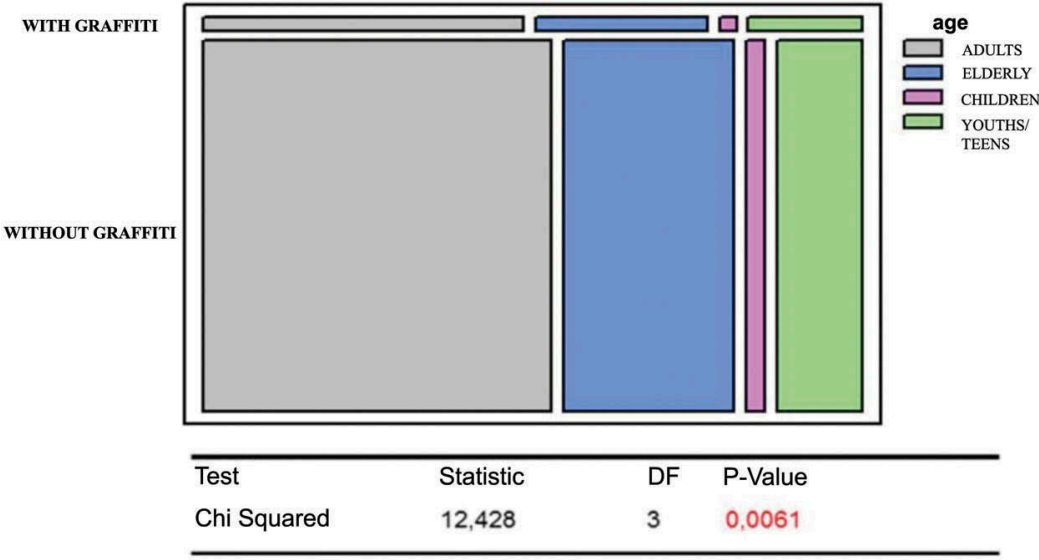

Figure 13. Mosaic graph for graffiti according to age and comparison test.

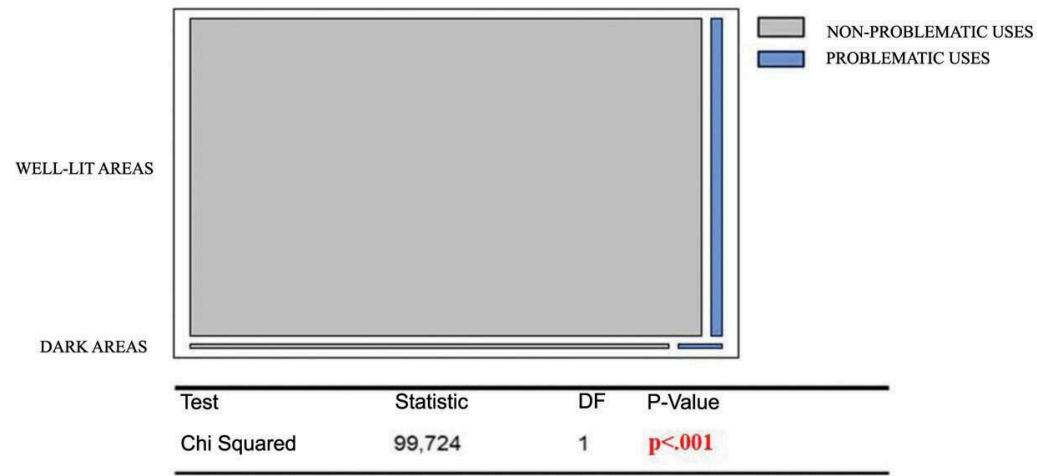

Figure 14. Mosaic graph for lighting according to problematic uses and comparison test.

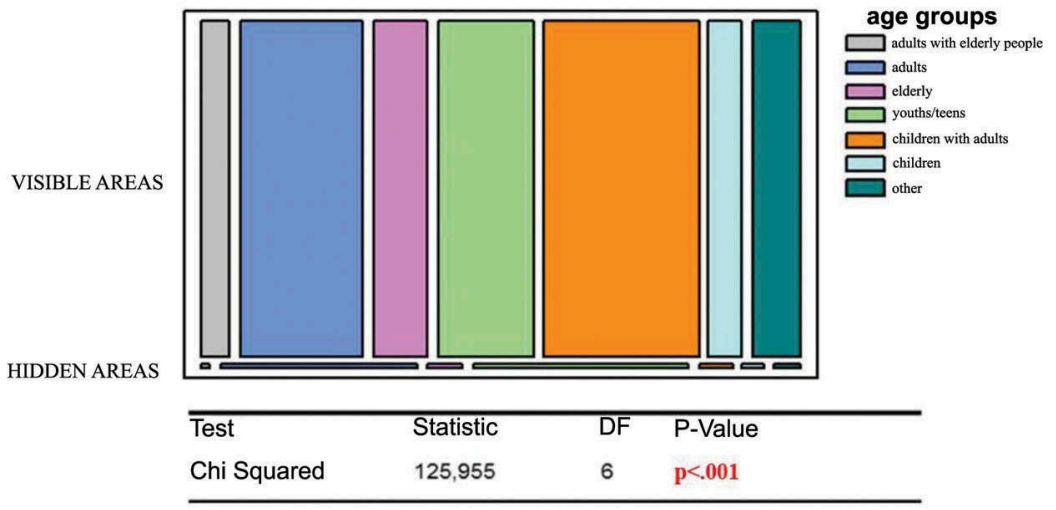

Figure 15. Mosaic graph for visual control according to age and comparison test. 


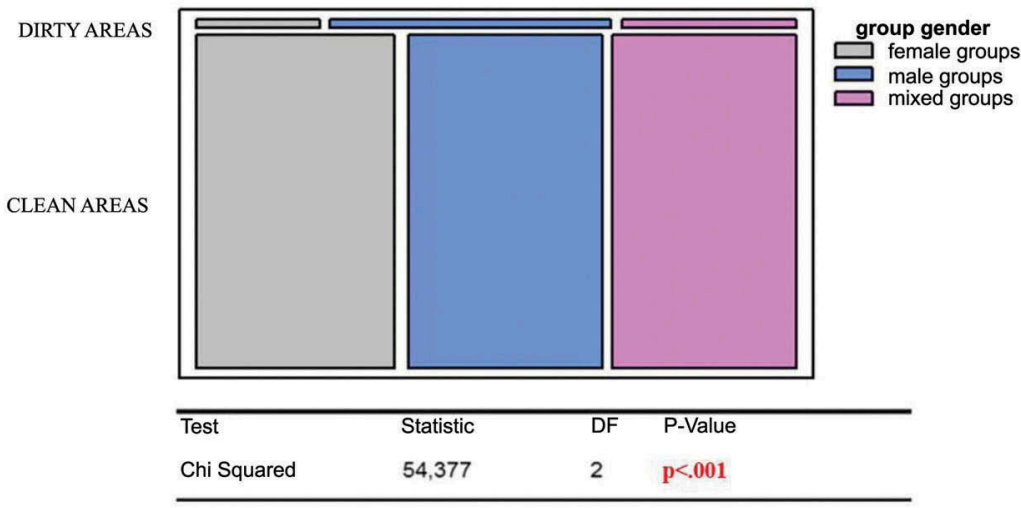

Figure 16. Mosaic graphs for cleanliness according to gender of groups and comparison test.

unit of observation is people on their own or in groups. Furthermore, elderly people are more present in certain spaces over others. In short, groups that generally perceive themselves to be more vulnerable (women and the elderly) have a lower presence in certain spaces in the city, which has ethical implications in terms of democratic access to public space and multiple negative consequences at an individual and community level. In turn, the presence of an ostensibly immigrant population in certain spaces (especially those that are more masculinized) is an interesting indicator of sociospatial segregation, although further investigation is required to understand the implications of this in the generation of feelings of insecurity and the avoidance of these spaces by other members of the public.

As regards activity, the quality and good functioning of a public space can be calibrated in accordance with the diversity of activities that take place there. Hence, according to Rueda (2002), the complexity of uses guarantees the good ecological functioning of the urban space, whereas Gehl (2006) proposes that the public space should promote uses and activities that are necessary (essential from a functional perspective) as well as optional (those that depend solely on the user's free decision), and, even though we did not detect a wide variety of uses in the parks and squares studied here — with being or talking in the space observed to be by far the most frequent activity - it has been possible to establish two profiles of spaces. On the one hand, those that present a major gap (in terms of absolute frequency) between this main activity and the other activities that take place there (which appear only as token activities). On the other hand, there are spaces that display a greater diversity of uses, introducing activities such as walking and playing, and which also normally involve a greater diversity of users. In this analysis, it is crucial to examine the variable of the timeslot in which observations were conducted, since the cadence of activities over the course of the day offers clearly distinctive characteristics depending on the two profiles of spaces. Once again, spaces that potentially generate feelings of a lack of safety are those that present a larger gap over the course of the different time slots. 
Environmental criteria present an important analytical difficulty: many of the record entries are characterized by being generated in an environment that is void of any remarkable aspects along the lines of the theoretical developments discussed previously. In spite of this, analysis of the environmental characteristics yields results that are in line with theories about lack of public safety: problematic behaviours are found in spaces with problematic lighting or visual control, whereas the subcriterion gender has an impact insofar as men appear in more hidden and concealed spaces and women avoid spaces that are dirtier or environmentally degraded.

This work is not without its limitations. Firstly, given that the observation sessions were conducted exclusively on working days and between the months of September and December 2010, any conclusions must be restricted to this observational period. In this respect, future research should explore changes in the patterns of uses in these types of public spaces during weekends, as well as during other seasons and times of year. Furthermore, even though at least two public spaces were observed in each of the 10 districts in the city of Barcelona, half of these spaces were located in just one district, Sants-Montjuïc, which leads us to exercise caution when interpreting the results. Finally, as with any observational study, this research must consider the possibility that the observers might have generated a reactance bias among the users of the public spaces studied, in spite of their instructions to be discreet during the observation and recording process.

EXOdES is an instrument that offers great potential when evaluating urban settings. The combination of field format and category systems offers multiple possibilities for the identification of spatial occupancy patterns based on multiple response levels. Although this instrument has been developed as a means of analysing possible criteria that characterize a space as potentially unsafe or conflictive, its scope goes beyond this, since in general the instrument offers an in-depth approach to the functioning of public urban spaces, regardless of their levels of potential danger or conflict. Its application to a sample of 40 spaces in the city of Barcelona has enabled certain interesting effects to be detected in terms of potential generation of a perceived lack of safety. Consequently, the evaluation of public space usage by means of the procedure shown here could provide information that would be of use when designing interventions in the space in terms of psycho-social initiatives and urban planning, or within the framework of public safety. In the near future, this observation and recording instrument will be available in a digital version, enabling data to be compiled directly in a digital format so they can be exported easily for subsequent analysis. 


\section{Evaluación de los usos y características ambientales de $\mathbf{4 0}$ parques y plazas en Barcelona mediante observación sistemática}

Los espacios públicos como las plazas, los jardines y los parques urbanos tienen múltiples beneficios en la salud física, psicológica y comunitaria de las personas. Este tipo de espacios favorecen la actividad física (Godbey, 2009), cuando constan de elementos naturales tienen efectos restauradores (Ulrich et al., 1991) y proporcionan el contexto idóneo para el desarrollo de la identidad de lugar, la cohesión social y el sentimiento de comunidad (Catell, Dines, Gesler \& Curtis, 2008). En una revisión cualitativa acerca del uso de los parques urbanos, se destaca la preocupación por la seguridad como la principal preocupación que llevaría a parte de la ciudadanía a evitar estos espacios, especialmente debido a la presencia de 'usuarios indeseables' como traficantes de drogas, vagabundos o personas sin hogar, y a otros aspectos relativos a la seguridad personal como la posibilidad de ser víctima de un delito o la presencia de vidrios o jeringuillas (McCormack, Rock, Toohey, \& Hignell, 2010).

La percepción de inseguridad ciudadana ha sido definida como 'el problema de nuestro tiempo' (Amerio \& Roccato, 2005). A diferencia del hecho de ser víctima de un delito, el miedo a poder serlo es algo que todas las personas experimentan en mayor o menor medida en algún momento de sus vidas. Sus efectos negativos a nivel individual incluyen ansiedad, sentimientos de rabia, frustración, desesperación, falta de confianza e insatisfacción vital (Miceli, Roccato, \& Rosato, 2004; Warr, 2000). Las medidas de evitación que las personas activan para reducir la probabilidad de ser víctimas de un delito incluyen la restricción de las propias rutinas, pasar más tiempo en casa, limitar las actividades externas a determinados espacios y momentos del día percibidos como más seguros y evitar atravesar determinadas zonas de la ciudad, utilizar el transporte público o salir de noche. La literatura suele coincidir en que estas restricciones sociales y espaciales con el fin de evitar situaciones de riesgo afectarían especialmente a mujeres (Gardner, 1990; Pain, 2000), personas mayores (Lindesay, 1996), e infantes (Valentine \& McKendrick, 1997).

A nivel comunitario, la percepción de inseguridad tiene importantes consecuencias. Algunas personas limitarían los contactos a determinados tipos de personas, evitando a extraños, grupos de jóvenes, personas de razas o grupos étnicos distintos o con ropa sucia o poca higiene personal (Miethe, 1995). Todo ello facilita una disminución de la cohesión social y la solidaridad, la fractura del sentido de comunidad y un menor control informal de las condiciones del propio barrio, lo cual contribuye a una mayor degradación de determinados enclaves y genera las condiciones idóneas para atraer a la delincuencia (Skogan, 1986). 
En cuanto a los factores ambientales, determinados aspectos del espacio tienen una relación más o menos directa con la percepción de inseguridad. Una adecuada iluminación, la existencia de zonas ocultas o de bajo control visual, la presencia de grafitis o signos de vandalismo y la presencia de suciedad o síntomas de abandono son algunos de los más importantes (Hunter, 1978; Lagrange, Ferraro, \& Supancic, 1992; Wilson \& Kelling, 1982).

A pesar de que diversas teorías y modelos han surgido para tratar de explicar los determinantes de la percepción de inseguridad (Carro, Valera, \& Vidal, 2010; Taylor \& Hale, 1986; Valera \& Guàrdia, 2014), mucha menos atención ha recibido el estudio de las consecuencias del miedo al delito en los patrones de utilización de los espacios públicos urbanos. Es una consecuencia lógica e ineludible para la Psicología Ambiental el tratar de articular métodos que permitan analizar los principales aspectos que son sensibles a la definición del espacio público y sus transformaciones. Conocer qué usos, actores y dinámicas de interacción caracterizan ciertos espacios urbanos sería el primer paso para detectar desigualdades en su acceso por parte de determinados grupos y potenciales conflictos de convivencia. Esto resulta especialmente importante en un momento en el que las ciudades están viviendo un proceso de complejización de los usos de su espacio público como consecuencia de una mayor diversidad, la existencia de nuevos actores sociales y el aumento de la brecha socioeconómica (Subirats, 2006) y en el que un buen número de autores empiezan a detectar la pérdida del espacio público urbano (Innerarity, 2006; Low, 2005; Low, Taplin, \& Scheld, 2005) en favor de un 'espacio privado de masas' mucho más controlado y panoptitzado es decir, más seguro (Low, 2003).

\section{Objetivos}

El objetivo principal es presentar un instrumento ad hoc de observación y registro de los usos de espacio público y características ambientales: EXOdES (Examen Observacional de Espacios). El instrumento se ha utilizado en el análisis de una muestra de 40 parques públicos y plazas de Barcelona. Se expondrá el procedimiento de registro de datos observacionales sincrónicos y se presentarán algunos resultados relacionales entre criterios correspondientes a los aspectos clave en el análisis de espacios públicos: tipología de usuarios, diversidad de usos y características ambientales. El trabajo también pretende, como segundo objetivo, efectuar un estudio exploratorio mediante la aplicación de la metodología observacional, que permita detectar, si los hay, patrones de ocupación del espacio público.

\section{Método}

\section{El contexto de investigación}

El trabajo de campo se realiza al amparo de un convenio de colaboración entre el Departamento de Psicología Social de la Universidad de Barcelona y la Dirección de Servicios de Prevención del Ayuntamiento de la ciudad. La muestra final de espacios públicos abarca 40 parques y plazas. Los criterios de selección incluyen la 
representatividad geográfica y una distribución proporcionalmente adecuada de espacios en función del nivel de seguridad-inseguridad - caracterizado a partir de la información de los técnicos de barrio, datos policiales y los datos de la Encuesta de Victimización de Catalunya. Además, se consideraron otros factores como proximidad (se configuran 10 rutas de observación de cuatro espacios cada una con un tiempo máximo de desplazamiento entre espacios de 15'), comunicabilidad, posibilidad de discreción del observador, etc. La Figura 1 presenta el conjunto de parques y plazas que configura la muestra final.

\section{Participantes}

Este estudio ha contado para la realización de las sesiones de observación con un equipo de 10 personas - no expertas en metodología observacional ni en psicología - que han sido coordinadas de forma conjunta entre la Dirección de Servicios de Prevención del Ayuntamiento de Barcelona y los investigadores de la Universidad de Barcelona. Durante un periodo de cinco semanas, el equipo fue formado en metodología observacional, en la utilización del instrumento de observación y registro y en el proceso de unificar los criterios a la hora de evaluar cada una de las dimensiones.

\section{Instrumento de observación}

El instrumento de observación que proponemos (EXOdES) incluye las seis siguientes dimensiones o macrocriterios, cada uno de los cuales se desglosa a continuación en subcriterios:

(1) Ubicación temporal: fecha de la sesión de observación y hora exacta de cada registro.

(2) Ubicación espacial: posición de cada usuario en el espacio público y ubicación concreta respecto a instalaciones o mobiliario existente.

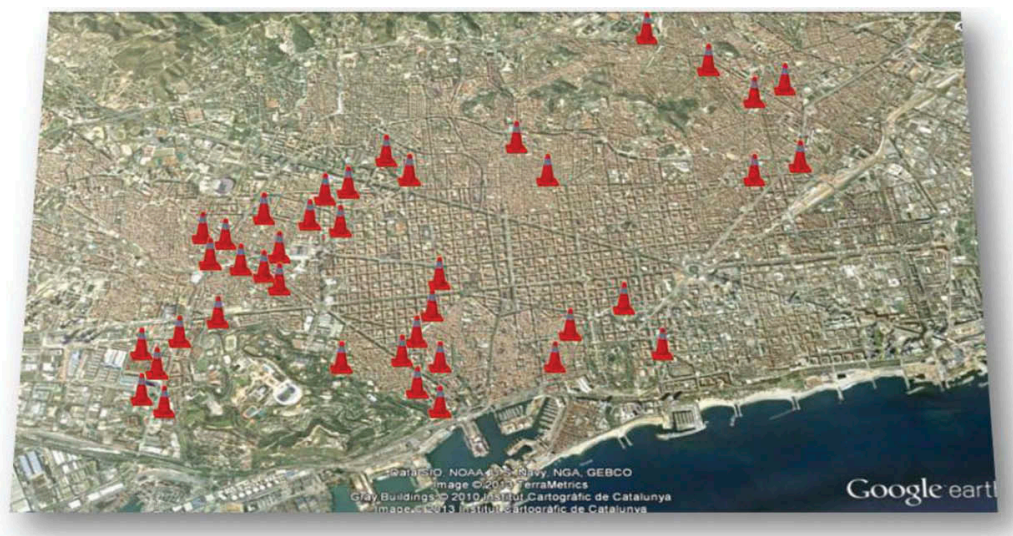

Figura 1. Los 40 espacios públicos analizados. 
(3) Descripción de los usuarios: Se tiene en cuenta género, franja de edad, personas solas o en grupo,

(4) Usos del espacio: actividades principales de los actores en el espacio público, presencia de vehículos, perros, síntomas evidentes de consumo de alcohol y/o sustancias, y violencia verbal y/o física.

(5) Factores psicosociales: origen aparentemente autóctono o inmigrante y potenciales signos de pertenencia a un determinado grupo social (por ejemplo, bandas latinas, turistas) o de pobreza (vagabundeo).

(6) Factores ambientales: caracterización del entorno más cercano respecto a iluminación, suciedad, grafitis, control visual, así como mantenimiento de papeleras, contenedores y zonas ajardinadas.

El instrumento de observación consta de 24 subcriterios, correspondientes a los seis criterios indicados, organizados en columnas (Figura 2). Cada fila corresponde al registro de cada una de las unidades de observación, en donde coocurren códigos correspondientes a los distintos subcriterios.

\section{Procedimiento}

Se plantea diseño observacional nomotético, con seguimiento intrasesional y multidimensional (Anguera, Blanco-Villaseñor, \& Losada, 2001). Los observadores han sido entrenados para pasar el máximo de desapercibidos posible por parte del resto de usuarios del espacio público. En cada caso, el observador debe elegir un lugar con buena visibilidad del espacio y donde pueda cómodamente observar y registrar todo lo que ocurre a su alrededor. El observador sigue siempre

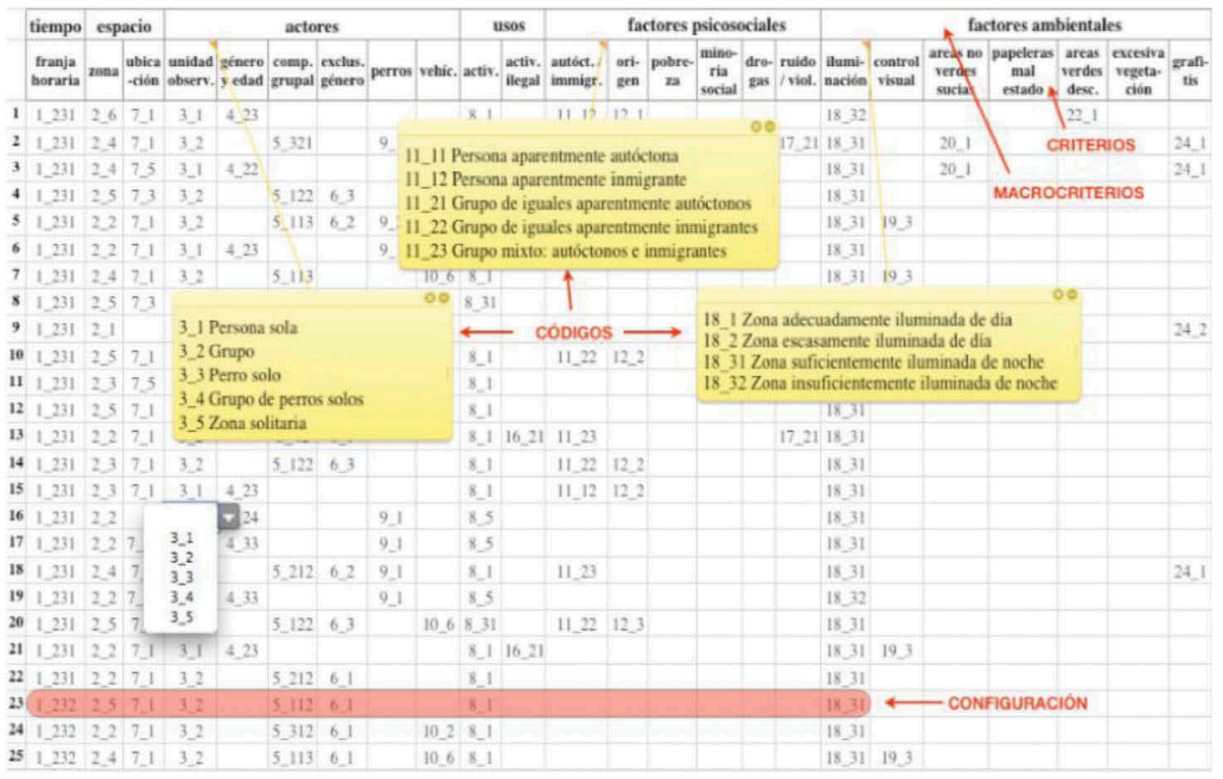

Figura 2. El instrumento EXOdES. 
un procedimiento de screening para el muestreo observacional intrasesional, consistente en observar y registrar un evento concreto que se ajusta a los criterios de selección establecidos (uso del espacio), sin tener en cuenta los eventos que suceden simultáneamente. Al finalizar el registro la atención se dirige hacia otro evento (otra fila en la matriz de códigos del registro) y así sucesivamente hasta completar la sesión. Para que todos los observadores pudieran situar a los usuarios de los espacios siguiendo un mismo criterio, se visitaron varias veces todos los espacios y se realizaron mapas con sus límites. En algunos casos el espacio tuvo que ser dividido en zonas siguiendo la lógica de la propia configuración espacial y los usos detectados.

Las sesiones de observación sucesivas en un mismo espacio y franja horaria son realizadas por varios observadores (mínimo tres distintos) para reducir sesgos individuales. Estas, a su vez, tienen lugar en días distintos de la semana (mínimo tres días distintos) para favorecer la heterogeneidad de usos encontrados. Se realizan entre 4-6 sesiones de observación en cada uno de los 40 espacios y en cada una de las ocho franjas horarias (cuatro de mañanas y cuatro de tardes) (Tabla 1). En condiciones climatológicas desfavorables se anulaba la sesión.

El resultado final arroja un total de 1,510 sesiones de observación de 45 minutos, lo cual permite disponer de 35,946 registros de actividades y de usuarios de los espacios públicos analizados (Tabla 1).

En cuanto al control de calidad del dato, los análisis de concordancia efectuados revelan niveles aceptables de fiabilidad inter-observadores y validez de criterio (Tabla 2).

\section{Resultados}

\section{Tipología de usuarios}

Los resultados obtenidos muestran, en términos generales un claro predominio de presencia masculina sobre la femenina, especialmente cuando la unidad de observación es persona sola. La proporción entre hombres y mujeres es de tres a uno, es decir que por cada mujer que usa el espacio público lo hacen tres

Tabla 1. Número de espacios públicos que fueron visitados de una a seis veces distintas en cada una de las franjas horarias establecidas.

\begin{tabular}{lcccccccc}
\hline & & 1 & 2 & 3 & 4 & 5 & 6 & \\
\hline Mañana & $10: 00$ a 11:00 & 40 & 40 & 40 & 40 & 30 & 2 & 192 \\
& $11: 00$ a 12:00 & 40 & 40 & 40 & 40 & 29 & 2 & 191 \\
& $12: 00$ a 13:00 & 40 & 40 & 40 & 40 & 29 & 2 & 191 \\
\multirow{4}{*}{ Tarde } & $13: 00$ a 14:00 & 40 & 40 & 40 & 40 & 27 & 1 & 188 \\
& $16: 00$ a 17:00 & 40 & 40 & 40 & 39 & 31 & 0 & 190 \\
& $17: 00$ a 18:00 & 40 & 40 & 40 & 39 & 30 & 0 & 189 \\
& $18: 00$ a 19:00 & 40 & 40 & 40 & 38 & 29 & 0 & 187 \\
& $19: 00$ a 20:00 & 40 & 40 & 40 & 38 & 24 & 0 & 182 \\
& & 320 & 320 & 320 & 314 & 229 & 7 & 1,510 \\
\hline
\end{tabular}




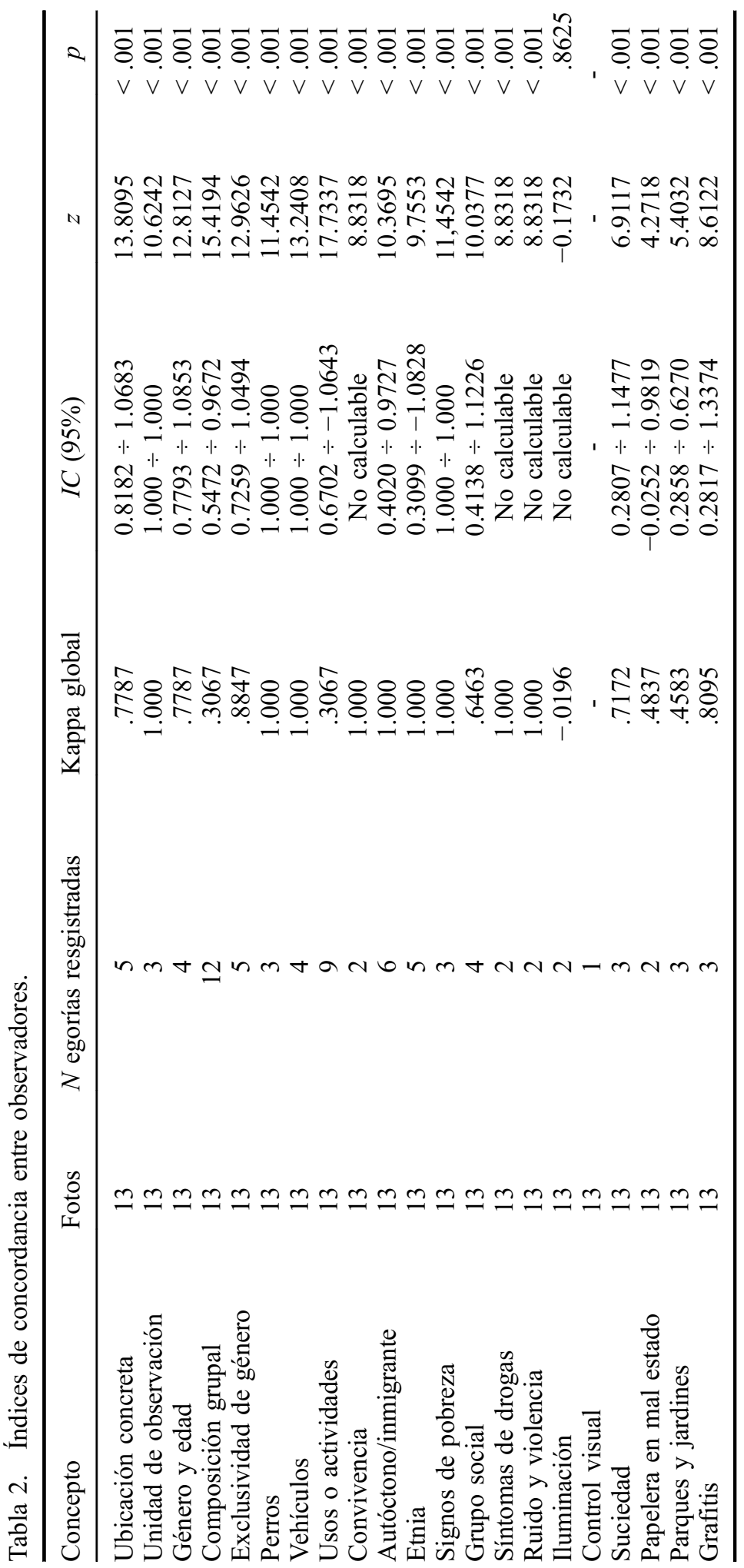




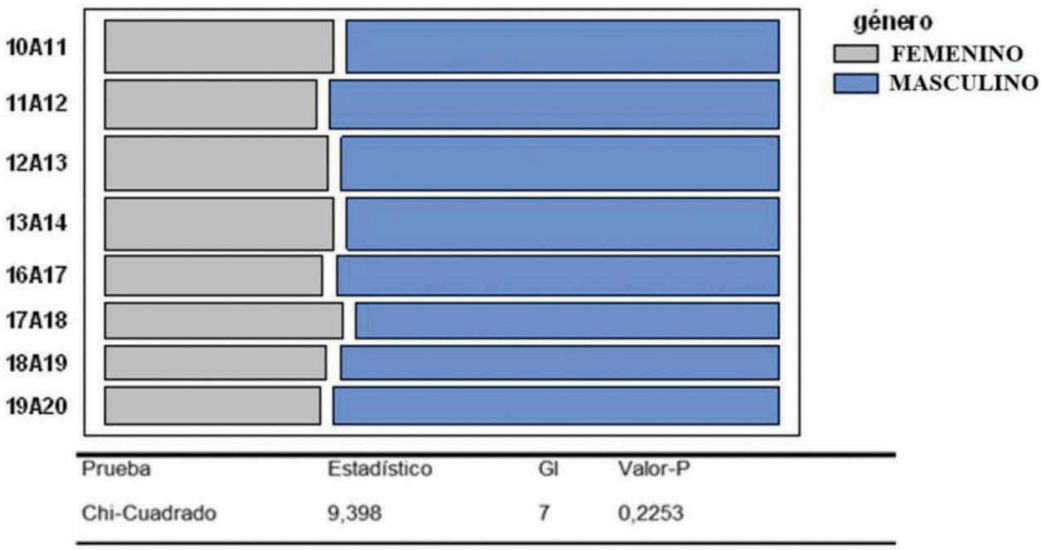

Figura 3. Gráfico mosaico para franja horaria según género y prueba de contraste.

hombres, diferencia que se mantiene estable a lo largo de las distintas franjas horarias (Figura 3).

Esta menor presencia de mujeres solas en el espacio público, se observa más en la población inmigrante $\left(\chi^{2}=97.69, g l=1, p=<.001\right)$ (Figura 4) y disminuye significativamente a medida que aumenta la edad $\left(\chi^{2}=192.978, g l=3\right.$, $p=<.001)$ (Figura 5).

En cuanto a los grupos de personas, la proporción de grupos formados exclusivamente por personas de la misma franja de edad difiere en función de los distintos espacios estudiados (Figura 6). Así, los grupos formados sólo por infantes representan el 6.54\% (IC 95\%: 2.99\%-10.08\%), los formados por jóvenes el 18.62\% (IC 95\%: $15.08 \%-22.16 \%$ ), por adultos el $24.27 \%$ (IC $95 \%$ : $20.72 \%-27.81 \%$ ) y por personas ancianas el 9.48\% (IC 95\%: 5.94\%-13.02\%). Lo mismo se observa también cuando comparamos la proporción de grupos de personas según el origen aparente (Figura 7). Los grupos formados sólo por personas aparentemente autóctonas representa el 75.00\% (IC 95\%: 73.12\%-76.88\%), los formados por personas aparentemente inmigrantes el $17.54 \%$ (IC 95\%: 15.66\%-19.42\%) y los grupos mixtos en cuanto al origen

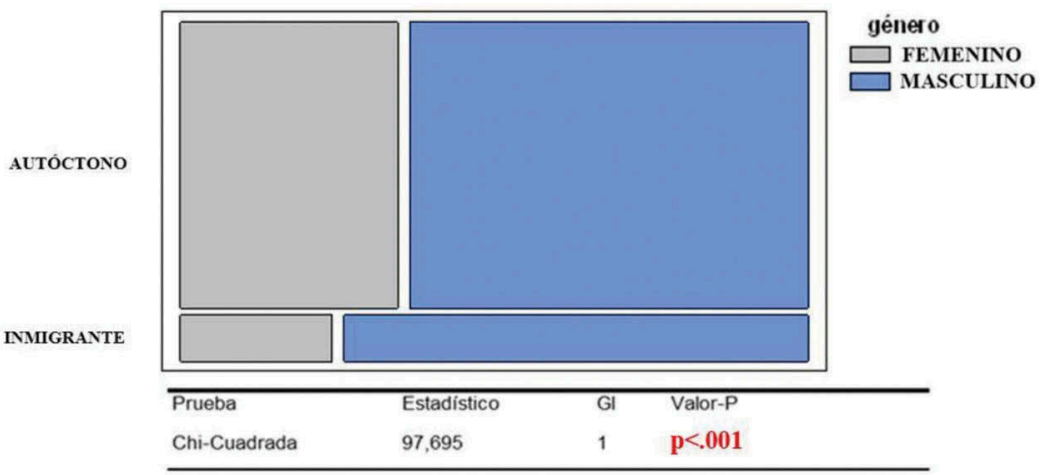

Figura 4. Gráfico mosaico para origen según género y prueba de contraste. 


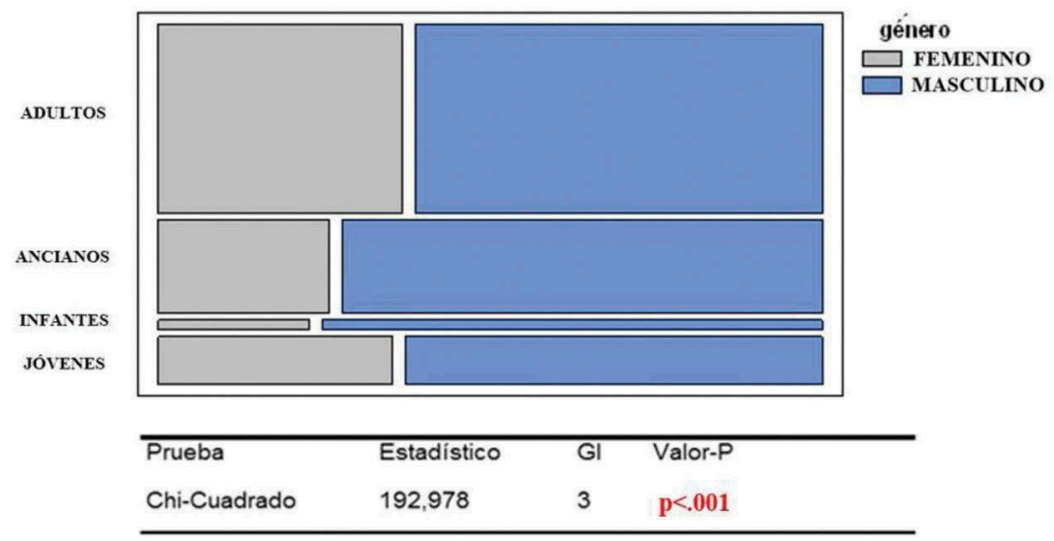

Figura 5. Gráfico mosaico para edad según género y prueba de contraste.

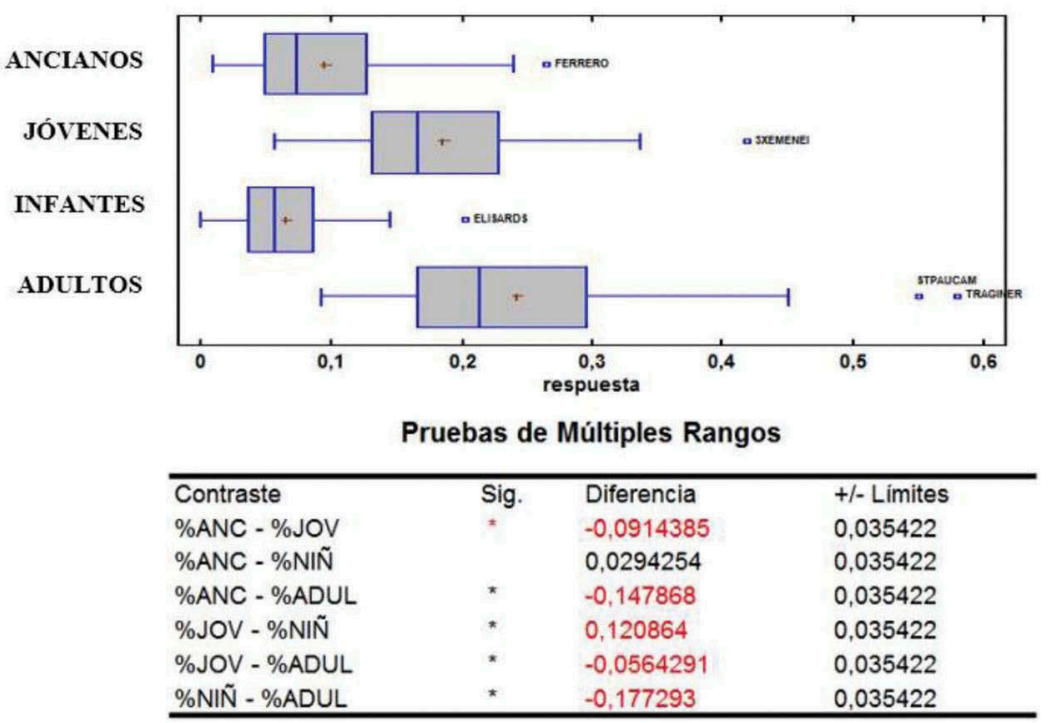

Figura 6. Gráficos de caja para espacios según edad y pruebas de contraste.

tan sólo el 7.43\% (IC 95\%: 5.54\%-9.31\%). Todo ello indica procesos de segregación espacial en función de la edad y el origen en los espacios estudiados.

El examen de estos datos a través del análisis de correspondencias todavía ofrece una mayor explicitación de estos efectos. La Figura 8 muestra claramente como los distintos espacios públicos analizados se distribuyen en función de los valores observacionales del subcriterio persona sola en función de un eje vertical 'presencia masculina/presencia femenina' $\mathrm{y}$, a su vez, forman tres constelaciones en torno a los valores jóvenes y adultos masculinos, niñas, jóvenes y adultas femeninas y personas ancianas, tanto masculinos como femeninos. En otras palabras, las personas mayores, las mujeres jóvenes y adultas, y los hombres jóvenes y adultos no se distribuyen de 


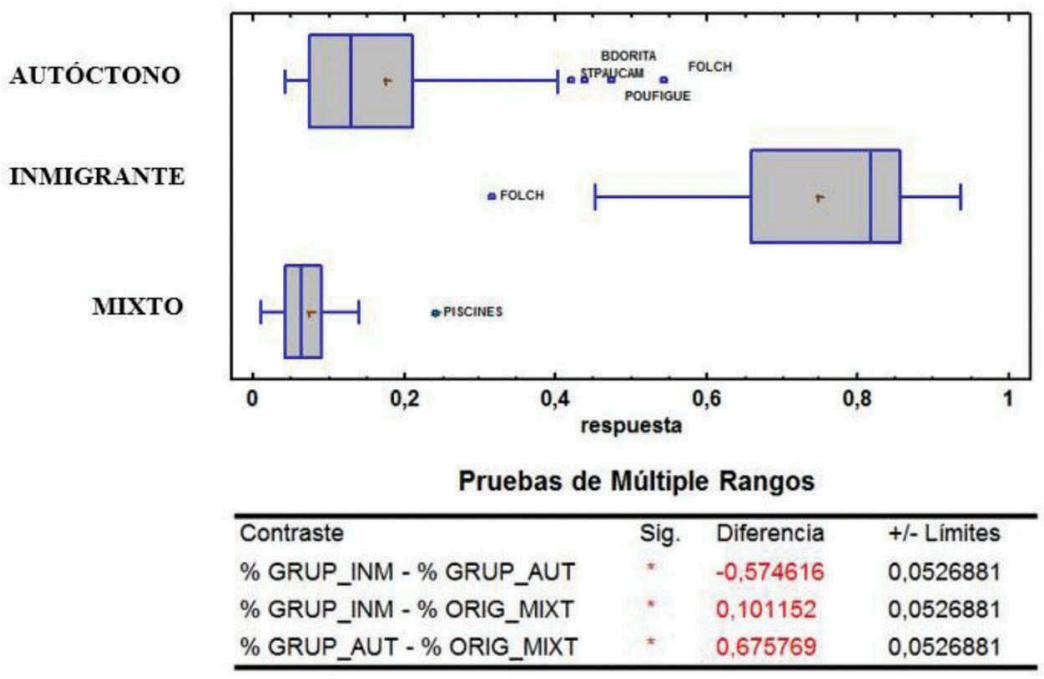

Figura 7. Gráficos de caja para espacios según origen y pruebas de contraste.

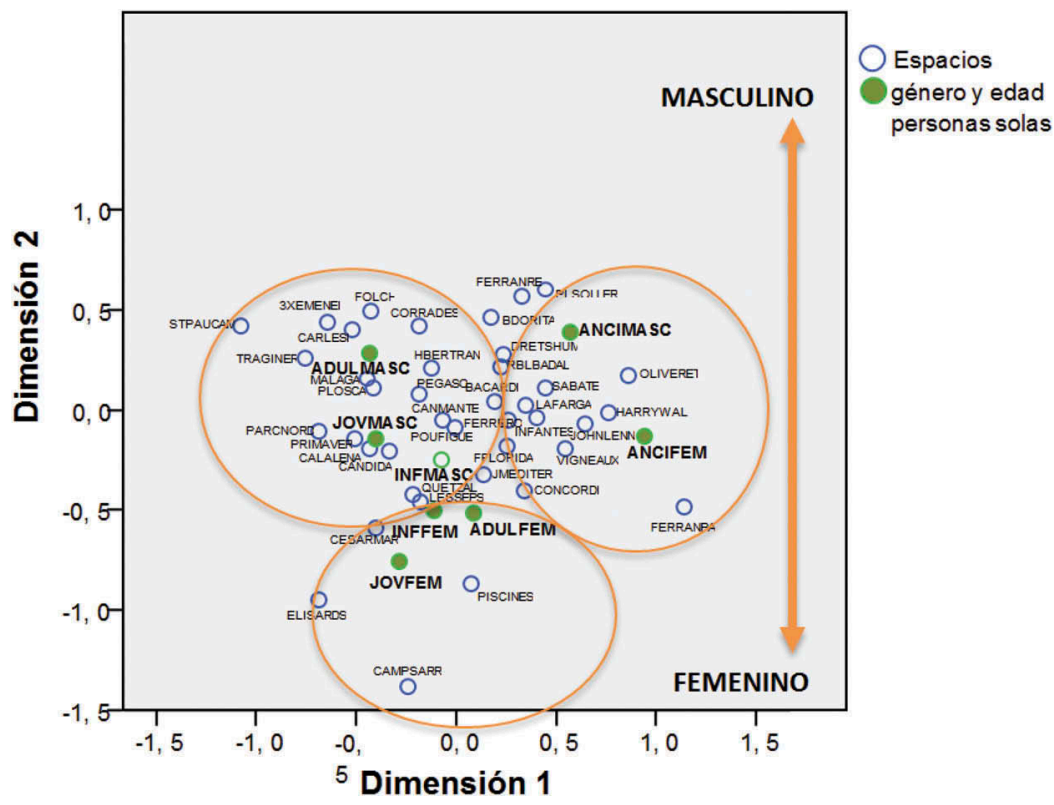

Figura 8. Resultados del análisis de correspondencias para el criterio género y edad de las personas solas.

manera homogénea en los espacios estudiados sino que es posible observar preferencias ambientales y procesos de segregación espacial en función de la edad y el género de las personas solas

La constatación de la caracterización de espacios en función del género también aparece meridianamente clara cuando la unidad de observación es grupos de personas. 


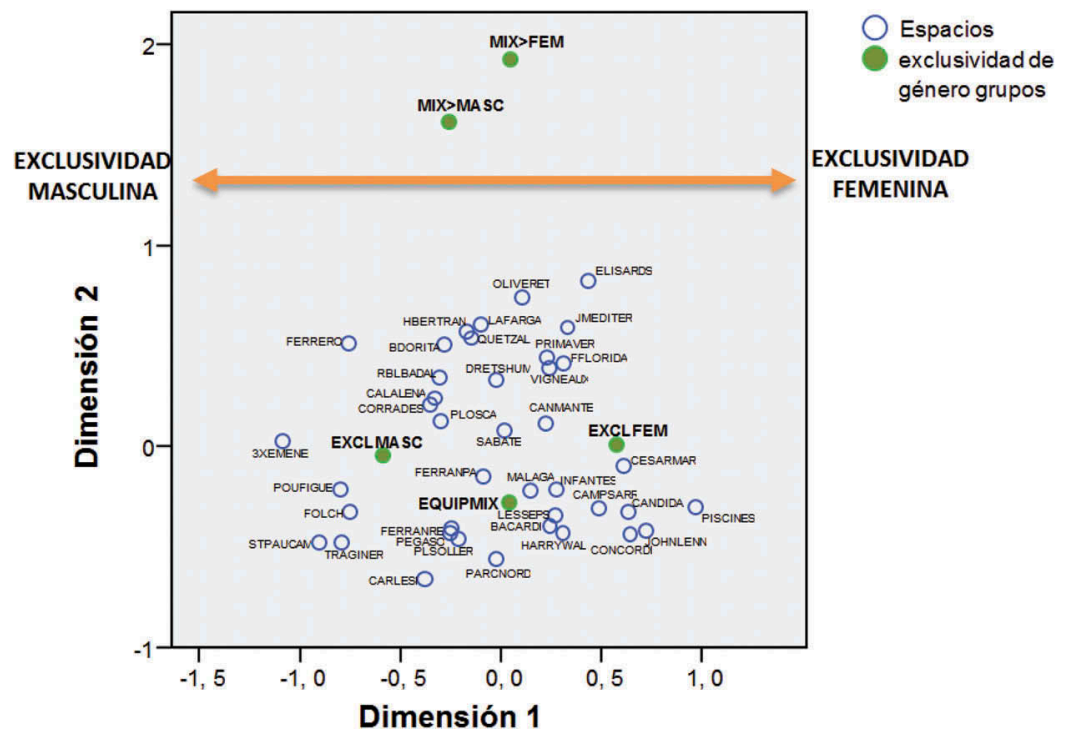

Figura 9. Resultados del análisis de correspondencias para el criterio género de los grupos.

La Figura 9 muestra como los parques y plazas analizados se distribuyen en el espacio euclidiano en función de un eje horizontal 'grupos exclusivamente masculinos/grupos exclusivamente femeninos'. Consecuentemente, observamos espacios donde la presencia de grupos formados exclusivamente por hombres o por mujeres es mucho más habitual.

Los espacios analizados también difieren en cuanto a la presencia de personas aparentemente autóctonas o inmigrantes. La Figura 10 muestra como la distribución de espacios y valores del subcriterio siguen un patrón vertical 'persona/grupo' y un patrón horizontal 'autóctono/inmigrante' de tal forma que observamos procesos de segregación espacial en cuanto al origen aparentemente autóctono o inmigrante de las personas que utilizan los espacios estudiados.

\section{Usos del espacio}

El análisis de correspondencias muestra una aglutinación de usos teniendo como elemento central la categoría estar o conversar en el espacio. A partir de este núcleo se configura un cinturón periférico que engloba actividades de paseo, de juego y de deporte (Figura 11)

El efecto más interesante aparece al observar la frecuencia de actividades y usos en función del espacio y la franja horaria. De esta forma se definen dos perfiles de espacios públicos: en primer lugar, espacios en los que, siendo la actividad principal estar $o$ conversar, ésta se diferencia extraordinariamente del resto de actividades en cuanto a su frecuencia. En otras palabras, hay un salto significativo entre ésta y el resto de usos, de muy baja frecuencia observada. La Figura 12 (a) muestra tres espacios representativos 


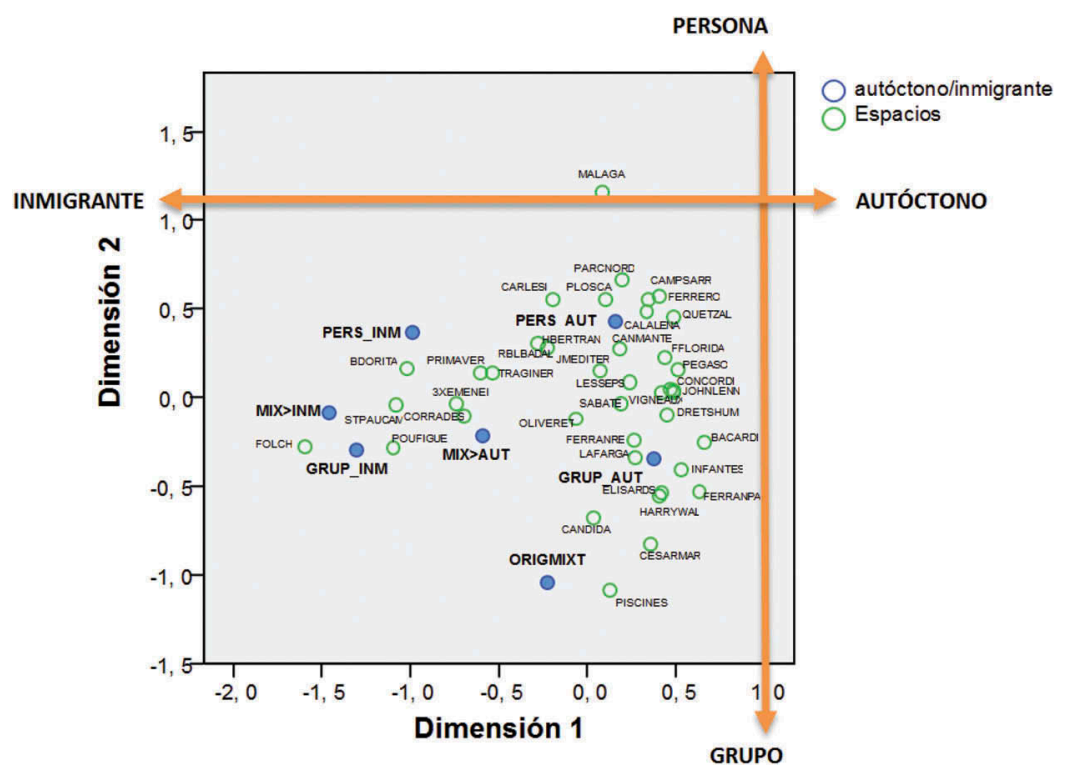

Figura 10. Resultados del análisis de correspondencias para el criterio origen aparente.

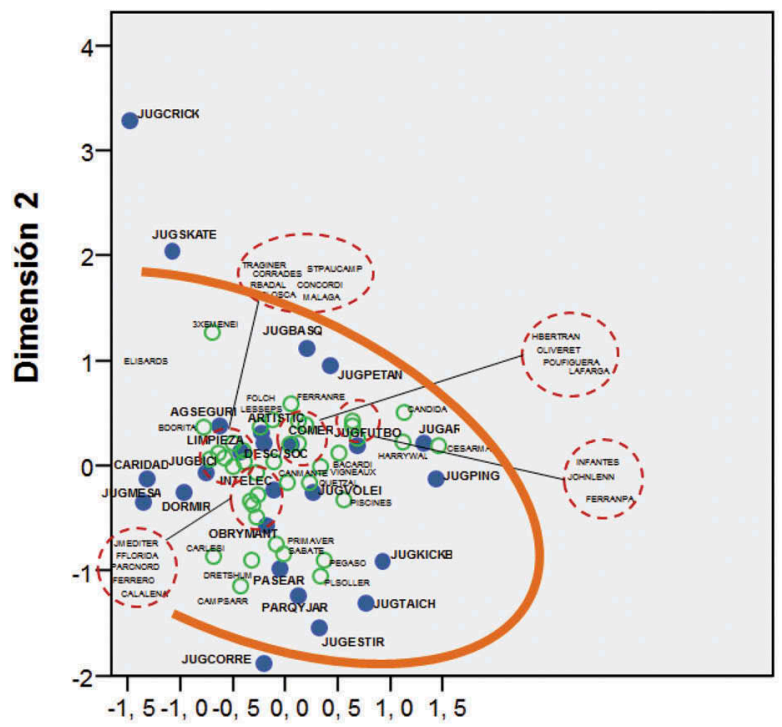

actividad principal

Espacios

Dimensión 1

Figura 11. Resultados del análisis de correspondencias para el criterio actividades en el espacio.

de este perfil en los que el límite de 20 observaciones por franja horaria marca la diferencia entre la actividad principal y el resto de actividades residuales.

Por otra parte, otro grupo de espacios se caracteriza por mostrar una mayor frecuencia de otras actividades además de la principal, y ello en la mayor parte de 
(a)
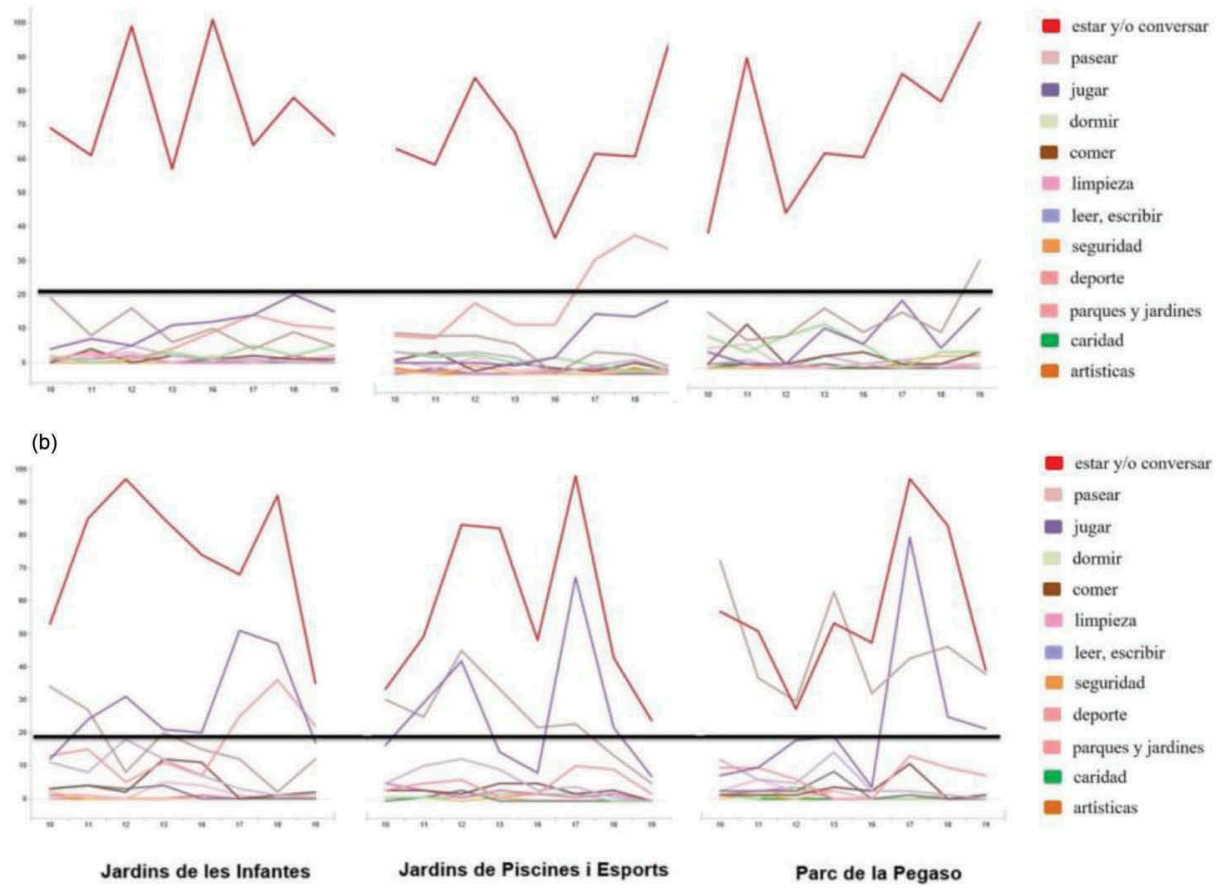

Figura 12. (a) Resultados de tres espacios representativos del perfil de baja diversidad de actividades en relación a las franjas horarias. (b) Resultados de tres espacios representativos del perfil de alta diversidad de actividades en relación a las franjas horarias.

franjas horarias. La diversidad de usos es, según puede observarse en la Figura 12 (b), la característica principal de estos espacios donde, además de estar y conversar aparecen usos como pasear o jugar.

\section{Factores ambientales}

La presencia de suciedad, vandalismo, problemas de iluminación o de control visual y síntomas de degradación ambiental aparecen con escasos porcentajes de incidencia. A pesar de ello, encontramos algunas relaciones estadísticamente significativas en la línea de los esperado teóricamente: se observa una mayor presencia de jóvenes en zonas con grafitis $\left(\chi^{2}=12.428, g l=3, p=.0061\right)$ (Figura 13), más usos problemáticos en zonas insuficientemente iluminadas $\left(\chi^{2}=99.724, g l=1, p<.001\right)$ (Figura 14), mayor presencia de grupos de hombres adultos y jóvenes en zonas ocultas $\left(\chi^{2}=125.955\right.$, $g l=6, p<.001$ ) (Figura 15) y un menor uso del espacio por parte de las mujeres en las zonas menos limpias $\left(\chi^{2}=54.377, g l=2, p<.001\right)$ (Figura 16).

\section{Discusión y conclusiones}

El espacio público debe garantizar en términos de igualdad la apropiación por parte de diferentes colectivos sociales y culturales, de género y de edad (Borja \& Muxí, 2000). 


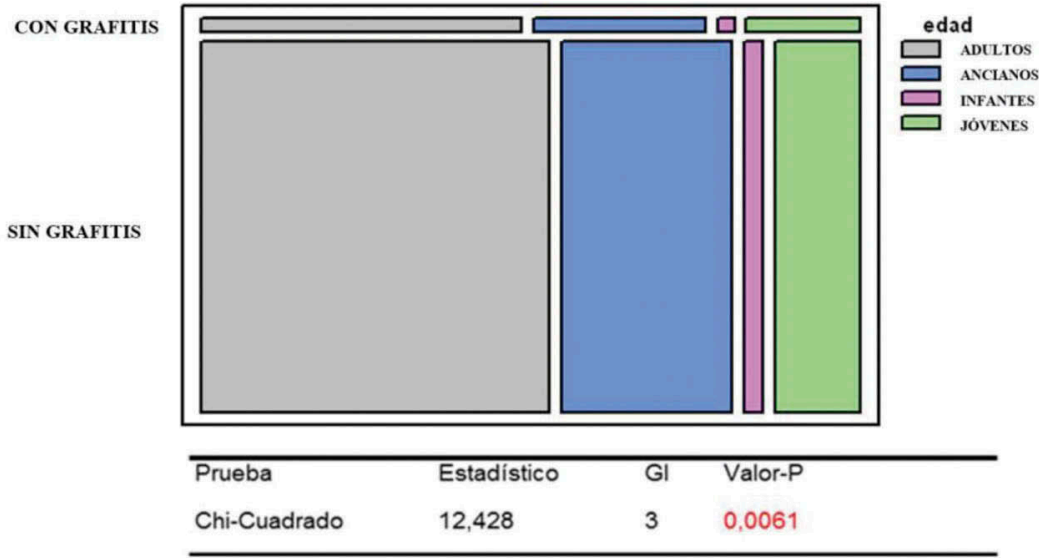

Figura 13. Gráfico mosaico para grafitis según edad y prueba de contraste.

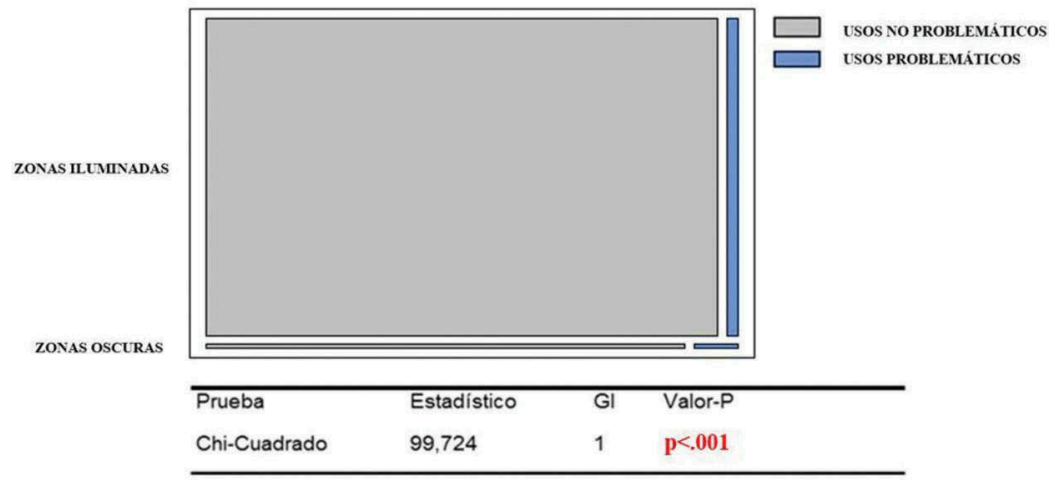

Figura 14. Gráfico mosaico para iluminación según usos problemáticos y prueba de contraste.

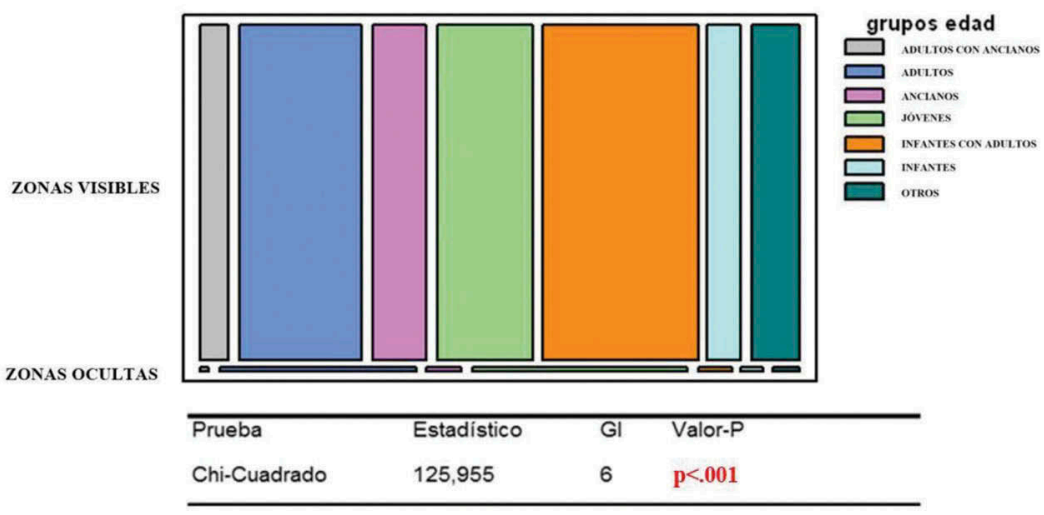

Figura 15. Gráfico mosaico para control visual según edad y prueba de contraste. 


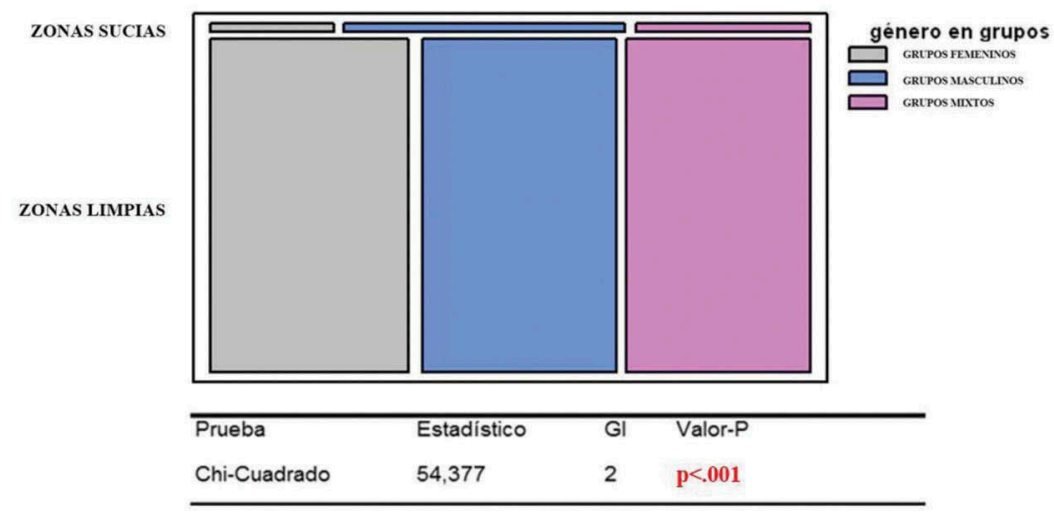

Figura 16. Gráfico mosaico para limpieza según género de grupos y prueba de contraste.

Conocer qué tipos de usuarios y actividades acoge un determinado espacio público nos proporciona información objetiva sobre los patrones de utilización de los espacios públicos. El análisis de los usuarios de los parques y plazas objeto de estudio arroja datos interesantes en cuanto a perfiles de espacios claramente diferenciados. En primer lugar, aunque realmente una gran cantidad de espacios se sitúan en posiciones mixtas o intermedias en cuanto al tipo de usuarios que acoge, un buen número está claramente polarizado sea por cuestión de género, de edad o de procedencia, y ello tanto si atendemos a personas solas como a grupos, lo cual refleja preferencias ambientales, conductas de evitación y procesos de segregación espacial. Se observan parques y plazas claramente masculinizados que contrastan con otros más feminizados o mixtos en cuanto al género, y ello tanto si la unidad de observación son las personas solas o los grupos. Por otra parte, la gente mayor también está más presente en determinados espacios que en otros. En definitiva, los grupos generalmente autopercibidos como más vulnerables (mujeres y ancianos) son aquellos que tienen menor presencia en determinados espacios de la ciudad, lo cual tiene implicaciones éticas en términos de acceso democrático al espacio público y múltiples consecuencias negativas a nivel individual y comunitario. A su vez, la presencia de población aparentemente inmigrante en determinados espacios (especialmente aquellos más masculinizados) es un interesante indicador de segregación socioespacial, aunque se requiere más investigación para comprender sus implicaciones en la generación de sentimientos de inseguridad y la evitación de estos espacios por una parte de la ciudadanía.

En cuanto a la actividad, la calidad y el buen funcionamiento de un espacio público puede calibrarse en función de la diversidad de actividades que acoge. Así, para Rueda (2002) la complejidad de usos garantiza el buen funcionamiento ecológico del espacio urbano mientras que Gehl (2006) propone que el espacio público debe promover usos o actividades tanto necesarias (imprescindibles funcionalmente) como optativas (aquellas que dependen únicamente de la decisión libre del usuario) y, especialmente, actividades sociales. El análisis de los usos del espacio muestra que, a pesar de que no se detecta una gran variedad 
de actividades en nuestras plazas y parques - siendo el estar en el espacio o conversar en él, con mucho, la actividad más frecuente - si ha sido posible establecer dos perfiles de espacios. Por un lado, aquellos que presentan una gran brecha (en términos de frecuencia absoluta) entre esta actividad principal y el resto (que entonces aparecen de manera meramente testimonial). Por otro, aquellos que muestran una mayor diversidad de usos, introduciéndose actividades como pasear o jugar y que, normalmente, involucran también a una mayor diversidad de usuarios. En este análisis resulta fundamental atender a la variable franja horaria ya que la cadencia de actividades a lo largo del día ofrece características claramente distintivas en función de los dos perfiles de espacios. Una vez más, los espacios potencialmente más generadores de sentimientos de inseguridad son aquellos que presentan una mayor brecha a lo largo de las distintas franjas horarias.

En cuanto a los criterios ambientales presentan una importante dificultad para el análisis: buena parte de los registros se caracterizan por generarse en un entorno ambiental desprovisto de aspectos remarcables en la línea de los desarrollos teóricos anteriormente comentados. A pesar de ello, el análisis de las características ambientales muestra resultados acordes con las teorías que abordan la inseguridad ciudadana: las conductas problemáticas se presentan en espacios con iluminación o control visual problemáticos mientras que el subcriterio género incide de forma que los hombres aparecen en espacios más ocultos y las mujeres evitan aquellos espacios más sucios o ambientalmente degradados.

Este trabajo no está exento de limitaciones. En primer lugar, dado que las sesiones de observación fueron realizadas exclusivamente durante días laborables y entre los meses de septiembre y diciembre del 2010, cualquier conclusión debe restringirse a este periodo observacional. En este sentido, convendría explorar en futuros trabajos cambios en los patrones de usos de este tipo de espacios públicos durante los fines de semana, así como durante otros periodos estacionales. Por otro lado, a pesar de que se observaron al menos dos espacios públicos de cada uno de los 10 distritos de la ciudad de Barcelona, la mitad de estos espacios estaban situados en un único distrito, el de Sants-Montjuïc, lo que nos llevaría a tener que interpretar cuidadosamente los resultados. Finalmente, como cualquier estudio observacional, este trabajo debe considerar la posibilidad de que los observadores hayan generado un sesgo de reactancia en los usuarios y usuarias de los espacios públicos estudiados, a pesar de las instrucciones de ser discretos durante el proceso de observación y registro.

El EXOdES se presenta como un instrumento de gran potencial para la evaluación de entornos urbanos. La combinación de formato de campo y sistemas de categorías ofrece múltiples posibilidades para la identificación de patrones de ocupación espacial en base a múltiples niveles de respuesta. A pesar de que este instrumento se desarrolla como una forma de analizar posibles criterios que caracterizan a un espacio como potencialmente inseguro o conflictivo, su alcance va más allá ya que de manera general el instrumento ofrece un acercamiento profundo al funcionamiento de los espacios públicos urbanos, independientemente de su nivel de peligrosidad o conflictividad. Su aplicación a una muestra de 40 
espacios de la ciudad de Barcelona ha permitido detectar algunos efectos interesantes tanto en términos de calidad social del espacio como en términos de potencial generación de percepción de inseguridad. En consecuencia, la evaluación de usos de espacios públicos mediante el procedimiento mostrado puede proporcionar información de utilidad para el diseño de intervenciones en el espacio de carácter psicosocial, urbanístico o en el marco de la seguridad ciudadana. En un futuro próximo este instrumento de observación y registro dispondrá de una versión en soporte informático que permita fácilmente la recogida de datos directamente en formato digital, así como su exportación para su posterior análisis.

\section{Acknowledgements / Agradecimentos}

This research was conducted as part of the project FBG 307946 Integració de dades procedents de metodologia observacional i de qüestionari per a l'anàlisi de l'espai públic de Barcelona en la prevenció de conflictes subsidized by the Department of Prevention Services of the Barcelona City Council; project La actividad fisica y el deporte como potenciadores del estilo de vida saludable: Evaluación del comportamiento deportivo desde metodologías no intrusivas [Grant number DEP2015-66069-P, MINECO/FEDER, $\mathrm{UE]}$; and project Avances metodológicos y tecnológicos en el estudio observacional del comportamiento deportivo [PSI2015-71947-REDP, MINECO/FEDER, UE]. In addition, the authors thank the support of the Generalitat de Catalunya Research Group, GRUP DE RECERCA I INNOVACIÓ EN DISSENYS (GRID). Tecnología i aplicació multimedia $i$ digital als dissenys observacionals [Grant number 2017 SGR 1405]. / Esta investigación se ha realizado dentro del proyecto FBG 307946 'Integració de dades procedents de metodologia observacional i de qüestionari per a l'anàlisi de l'espai públic de Barcelona en la prevenció de conflictes'subvencionado por la Dirección de Servicios de Prevención del Ayuntamiento de Barcelona; el proyecto DEP2015-66069-P 'La actividad fisica y el deporte como potenciadores de estilo de vida saludable: Evaluación del comportamiento deportivo desde metodologías no intrusivas'subvencionado por la Dirección General de Investigación Científica y Técnica del Ministerio de Economía y Competitividad; y el proyecto Avances metodológicos y tecnológicos en el estudio observacional del comportamiento deportivo [PSI2015-71947-REDP, MINECO/FEDER, UE]. Los autores agradecen el soporte del Grupo de Investigación de la Generalitat de Catalunya, GRUP DE RECERCA I INNOVACIÓ EN DISSENYS (GRID). Tecnología i aplicació multimedia $i$ digital als dissenys observacionals [Grant number 2017 SGR 1405].

\section{Disclosure statement}

No potential conflict of interest was reported by the authors. / Los autores no han referido ningún potencial conflicto de interés en relación con este artículo.

\section{ORCID}

Sergi Valera (i) http://orcid.org/0000-0002-6820-4697

M. Teresa Anguera (i) http://orcid.org/0000-0001-7147-2927 


\section{References / Referencias}

Amerio, P., \& Roccato, M. (2005). A predictive model for psychological reactions to crime in Italy: An analysis of fear of crime and concern about crime as a social problem. Journal of Community Applied Social Psychology, 15, 17-28. doi:10.1002/ casp. 806

Anguera, M. T., Blanco-Villaseñor, A., \& Losada, J. L. (2001). Diseños Observacionales, cuestión clave en el proceso de la metodología observacional. Metodología de las Ciencias del Comportamiento, 3, 135-161.

Borja, J., \& Muxí, Z. (2000). El espacio público, ciudad y ciudadanía. Barcelona: Diputació de Barcelona.

Carro, D., Valera, S., \& Vidal, T. (2010). Perceived insecurity in the public space: Personal, social and environmental variables. Quality and Quantity, 44, 303-314. doi:10.1007/s11135-008-9200-0

Cattell, V., Dines, N., Gesler, W., \& Curtis, S. (2008). Mingling, observing, and lingering: Everyday public spaces and their implications for well-being and social relations. Health and Place, 14, 544-561. doi:10.1016/j.healthplace.2007.10.007

Gardner, C. B. (1990). Safe conduct: Women, crime and self in public places. Social Problems, 37, 311-328. doi:10.2307/800745

Gehl, J. (2006). La humanizacion del espacio urbano: La vida social entre los edificios. Madrid: Reverte (Original edition: London: Island Press, 1987).

Godbey, G. (2009). Outdoor recreation, health, and wellness: Understanding and enhancing the relationship. Prepared for the Outdoor Resources Review Group Resources for the Future Background Study.

Hunter, A. (1978). Symbols of incivility: Social disorder and fear of crime in urban neighborhoods. Paper presented at the Annual Meeting of the American Society of Criminology. Dallas, TX, United States of America.

Innerarity, D. (2006). El Nuevo espacio público. Barcelona: Espasa.

Lagrange, R., Ferraro, K., \& Supancic, M. (1992). Perceived risk and fear of crime: Role of social and physical incivilities. Journal of Research in Crime and Delinquency, 29, 311-334. doi:10.1177/0022427892029003004

Lindesay, J. (1996). Eldery people and crime. Review in Clinical Gerontology, 6, 199204. doi:10.1017/S0959259800004664

Low, S. (2003). Behind the gates: Life, security, and the pursuit of happiness in fortress america. New York, NY: Routledge.

Low, S. (2005). Transformaciones del espacio público en la ciudad latinoamericana: Cambios espaciales y prácticas sociales. Bifurcaciones, 5, 1-14.

Low, S., Taplin, D., \& Scheld, S. (2005). Rethinking urban parks: Public space and cultural diversity. Austin, TX: University of Texas Press.

McCormack, G. R., Rock, M., Toohey, A. M., \& Hignell, D. (2010). Characteristics of urban parks associated with park use and physical activity: A review of qualitative research. Health \& Place, 16, 712-726. doi:10.1016/j.healthplace.2010.03.003

Miceli, R., Roccato, M., \& Rosato, R. (2004). Fear of crime in Italy: Spread and determinants. Environment and Behavior, 36, 776-789. doi:10.1177/0013916503261931

Miethe, T. D. (1995). Fear and withdrawal from urban life. Annals of the American Academy of Political and Social Science, 539, 14-28. doi:10.1177/0002716295539001002

Pain, R. (2000). Place, social relations and the fear of crime: a review. Progress in Human Geography, 24, 365-387.

Rueda, S. (2002). Barcelona, ciutat mediterrània, compacta i complexa. Una visió de futur més sostenible. Barcelona: Ed. Ayuntamiento de Barcelona.

Skogan, W. G. (1986). The fear of crime and its behavioral implications. In E. A. Fattah (Ed.), From crime policy to victim policy: Reorienting the justice system (pp. 167188). London: Macmillan. 
Subirats, J. (2006). Apunts sobre espai públic, convivència i ciutadania. Nous Horitzons, $183,8-14$.

Taylor, R. B., \& Hale, M. (1986). Testing alternative models of fear of crime. Journal of Criminal Law and Criminology, 77, 151-189. doi:10.2307/1143593

Ulrich, R. S., Simons, R. F., Losito, B. D., Fiorito, E., Miles, M. A., \& Zelson, M. (1991). Stress recovery during exposure to natural environments. Environmental Psychology, 11, 201-230. doi:10.1016/S0272-4944(05)80184-7

Valentine, G., \& McKendrick, J. (1997). Children's outdoor play: Exploring parental concerns about children's safety and the changing nature of childhood. Geoforum, 28, 219-235. doi:10.1016/S0016-7185(97)00010-9

Valera, S., \& Guàrdia, J. (2014). Perceived insecurity and fear of crime in a city with lowcrime rates. Journal of Environmental Psychology, 38, 195-205. doi:10.1016/j. jenvp.2014.02.002

Warr, M. (2000). Fear of crime in the United States: Avenues for research and policy. Measurement and Analysis of Crime and Justice, 4, 451-489.

Wilson, J. Q., \& Kelling, G. L. (1982). Broken windows. The Atlantic Online. 